\title{
Start van de loopbaan na de Universiteit Maastricht 1995/1996
}

Citation for published version (APA):

Ramaekers, G. W. M. (1997). Start van de loopbaan na de Universiteit Maastricht 1995/1996.

Researchcentrum voor Onderwijs en Arbeidsmarkt, Faculteit der Economische Wetenschappen. ROA Reports No. 6 https://doi.org/10.26481/umarep.1997006

Document status and date:

Published: 01/01/1997

DOI:

10.26481/umarep.1997006

Document Version:

Publisher's PDF, also known as Version of record

\section{Please check the document version of this publication:}

- A submitted manuscript is the version of the article upon submission and before peer-review. There can be important differences between the submitted version and the official published version of record.

People interested in the research are advised to contact the author for the final version of the publication, or visit the DOI to the publisher's website.

- The final author version and the galley proof are versions of the publication after peer review.

- The final published version features the final layout of the paper including the volume, issue and page numbers.

Link to publication

\footnotetext{
General rights rights.

- You may freely distribute the URL identifying the publication in the public portal. please follow below link for the End User Agreement:

www.umlib.nl/taverne-license

Take down policy

If you believe that this document breaches copyright please contact us at:

repository@maastrichtuniversity.nl

providing details and we will investigate your claim.
}

Copyright and moral rights for the publications made accessible in the public portal are retained by the authors and/or other copyright owners and it is a condition of accessing publications that users recognise and abide by the legal requirements associated with these

- Users may download and print one copy of any publication from the public portal for the purpose of private study or research.

- You may not further distribute the material or use it for any profit-making activity or commercial gain

If the publication is distributed under the terms of Article $25 \mathrm{fa}$ of the Dutch Copyright Act, indicated by the "Taverne" license above, 
Start van de loopbaan

na de Universiteit Maastricht

1995/1996

ROA-R-1997/6

G.W.M. Ramaekers

Researchcentrum voor Onderwijs en Arbeidsmarkt

Faculteit der Economische Wetenschappen en Bedrijfskunde Universiteit Maastricht

Maastricht, augustus 1997 
ISBN 90-5321-211-6

SEC97104 


\section{Inhoud}

Bladzijde

Voorwoord

Samenvatting

1 Inleiding 1

1.1 Opzet Arbeidsmarktscanner UM 1

1.2 Leeswijzer 2

2 Ontwikkeling loopbaan cohort '90 5

2.1 Respons op loopbaanmeting 1996

2.2 Mobiliteit na afstuderen 6

2.3 Deelname aan post-doctoraal onderwijs 8

$\begin{array}{ll}2.4 \text { Veranderingen in kans op werk } & 10\end{array}$

$\begin{array}{ll}2.5 \text { Veranderingen in kwaliteit van het werk } & 11\end{array}$

3 Analyse van de kwaliteit van het latere werk 17

4 Afstemming tussen opleiding en later werk 27

$\begin{array}{ll}4.1 \text { Inhoudelijke discrepanties en PGO } & 27\end{array}$

4.2 Analyse van het belang van kwalificaties $\quad 34$

$\begin{array}{ll}4.3 \text { Analyse van de gewenste aandacht voor kwalificaties } & 37\end{array}$

5 Ontwikkelingen in de intrede op de arbeidsmarkt tussen afstudeercohorten '90-'94

Bijlage 1 Publicaties in het kader van de Arbeidsmarktscanner Universiteit Maastricht

Bijlage 2 Facultaire tabellen betreffende de afstemming tussen opleiding en later werk

Bijlage 3 Definitie van variabelen in de schattingen 



\section{Voorwoord}

Het Researchcentrum voor Onderwijs en Arbeidsmarkt (ROA), dat verbonden is aan de Faculteit der Economische Wetenschappen en Bedrijsskunde van de Universiteit Maastricht (UM), verricht sinds 1990 periodiek onderzoek naar de arbeidsmarktpositie en loopbanen van afgestudeerden van de UM. Dit gebeurt met behulp van de zogeheten 'Arbeidsmarktscanner UM'. De systematiek van deze scanner, zoals deze thans aan de UM wordt toegepast, bestaat hieruit dat oudstudenten voor de eerste keer circa anderhalf jaar na het afstuderen worden bevraagd met behulp van een basisvragenlijst (de basismeting, waarmee de transitie van studie naar werk wordt gemeten). Zo'n vijfeneenhalf jaar na het afstuderen worden zij voor de tweede keer geënquêteerd met een loopbaanvragenlijst (de loopbaanmeting). Door de gegevens van de basismeting te vergelijken met die van de loopbaanmeting kunnen ontwikkelingen in de loopbaan worden getraceerd. Het voornemen is om de arbeidsmarktscanner UM met ingang van 1998 structureel uit te breiden met een derde meting, die tien jaar na het afstuderen plaatsvindt. Hierdoor kan ook de verdere ontwikkeling van de loopbaan in kaart worden gebracht.

In het nu voorliggende rapport worden resultaten gepresenteerd van de eind 1995/begin 1996 gehouden basismeting onder degenen die in 1994 aan de UM zijn afgestudeerd. De resultaten van deze basismeting worden afgezet tegen de resultaten van de vier hieraan voorafgaande basismetingen onder respectievelijk afstudeercohort '90, '91, '92 en '93. Hierdoor kan worden nagegaan hoe de transitie van studie naar werk zich in de eerste helft van de negentiger jaren heeft ontwikkeld.

Daarnaast worden resultaten gepresenteerd van de in het voorjaar van 1996 gehouden loopbaanmeting onder degenen die in 1990 aan de UM zijn afgestudeerd. De resultaten van deze loopbaanmeting worden vergeleken met de resultaten van de basismeting die in 1991 onder afstudeercohort ' 90 is verricht. Hierdoor kunnen ontwikkelingen in de loopbaan van de desbetreffende afgestudeerden worden getraceerd. Tot slot zijn resultaten opgenomen betreffende de inhoudelijke afstemming tussen opleiding en werk, die eenmalig in een eerder verrichte loopbaanmeting aan de orde is gesteld.

De arbeidsmarktscanner wordt aan de UM toegepast in opdracht van het College van Bestuur. De toepassing vindt plaats in samenwerking met het Bureau Inschrijvingen van de Dienst Studentenzaken van de UM. Het Bureau Inschrijvingen zorgt voor het bijhouden van het adressenbestand van de alumni, het verzenden van de vragenlijsten en de non-responsactiviteiten. Het ROA is verantwoordelijk voor de methodologische en inhoudelijke aspecten van de arbeidsmarktscanner, stelt de jaarlijkse rapportages samen en beheert het bestand met onderzoeksgegevens. Het onderzoek wordt binnen het Bureau Inschrijvingen uitgevoerd door L. Gray en $\mathrm{H}$. Smit en binnen het ROA door drs. G.W.M. Ramaekers (projectleider) met medewer- 
king van J.M.J.A. Pisters. Het project wordt intern begeleid door dr. R.K.W. van der Velden.

Zoals eerder gezegd, verricht het ROA sinds 1990 jaarlijks onderzoek naar de arbeidsmarktpositie van afgestudeerden - waaronder economen - van de UM. Vanaf 1994 verricht het ROA tevens basismetingen onder afgestudeerde economen van de Erasmus Universiteit Rotterdam en de Katholieke Universiteit Brabant (de WOMonitor Economie). In het najaar van 1996 is de WO-Monitor Economie uitgebreid met de economische faculteiten van de Universiteit van Amsterdam en de Vrije Universiteit. Daarnaast heeft het ROA inmiddels de eerste basismeting onder afgestudeerden van de Technische Universiteit Delft verricht.

Maastricht, augustus 1997 


\section{Samenvatting}

In het kader van het onderzoeksproject 'Arbeidsmarktscanner UM' worden jaarlijks twee metingen verricht onder afgestudeerden van de Universiteit Maastricht (UM), de zogeheten basismeting die zo' $n$ anderhalf jaar na het afstuderen plaatsvindt $(t+1$ meting) en de loopbaanmeting die zo'n vijfeneenhalf jaar na het afstuderen wordt gehouden ( $t+5$ meting). Dit rapport doet verslag van de eind 1995/begin 1996 gehouden basismeting onder degenen die in kalenderjaar 1994 aan de UM zijn afgestudeerd en van de voorjaar 1996 gehouden loopbaanmeting onder degenen die in kalenderjaar 1990 aan de UM zijn afgestudeerd. Aangezien afstudeercohort '90 vier jaar eerder (eind 1991/begin 1992) met behulp van de basismeting is geënquêteerd, kunnen ontwikkelingen in de eerste jaren van de loopbaan van cohort ' 90 in kaart worden gebracht. Door de resultaten van de basismeting onder cohort '94 te vergelijken met de resultaten van basismetingen van eerdere cohorten wordt nagegaan hoe de transitie van studie naar werk zich in de loop der jaren heeft ontwikkeld.

\section{Ontwikkeling van de loopbaan}

Ontwikkelingen in de loopbaan van afstudeercohort '90 worden geschetst aan de hand van de geografische- en baanmobiliteit, de deelname aan vervolgopleidingen en de veranderingen in de kans op werk en kwaliteit van het werk.

\section{Mobiliteit}

Zo'n vijfeneenhalf jaar na het afstuderen is vrijwel niemand meer in de intredebaan werkzaam: ruim $90 \%$ is dan al eens van werkgever veranderd $(43 \%$ is al in de eerste anderhalf jaar na het afstuderen van werkgever veranderd). Ongeveer evenveel oudstudenten starten hun loopbaan op de regionale arbeidsmarkt (de provincie Limburg) als op de landelijke arbeidsmarkt. Na verloop van tijd gaan meer oudstudenten op de landelijke arbeidsmarkt werken.

\section{Deelname aan vervolgopleidingen}

Zo'n vijfeneenhalf jaar na het afstuderen beschikt een kwart (26\%) van de oudstudenten over formele additionele kwalificaties in de vorm van een voltooide tweede fase-opleiding of post-doctorale beroepsopleiding. Een op de 20 oudstudenten is ten tijde van de $t+5$ meting tot doctor (dr.) gepromoveerd. De meerderheid $(62 \%)$ van de oudstudenten heeft behoefte aan bijscholing.

\section{Kans op werk}

Op het moment van de $t+5$ meting heeft vrijwel iedereen een betaalde baan: het aandeel van betaald-werkenden stijgt van $83 \%$, gemeten anderhalf jaar na afstude- 
ren naar $96 \%$, gemeten vijfeneenhalf jaar na afstuderen. Het aandeel van werkzoekenden daalt tussen beide meetmomenten van $5 \%$ naar $1 \%$. Alle oudstudenten die zo'n anderhalf jaar na het afstuderen nog werkzoekend waren, blijken vier jaar later een betaalde baan te hebben.

\section{Kwaliteit van het werk}

Ruim driekwart $(79 \%)$ van de oudstudenten start de loopbaan in een functie op academisch niveau en is zo'n vier jaar later (nog steeds) op academisch niveau werkzaam. Van degenen die de loopbaan starten in een functie onder hun opleidingsniveau is bijna de helft (42\%) vier jaar later doorgegroeid naar een functie die wel past bij het niveau van de genoten opleiding. Dit betekent dat $86 \%$ al dan niet rechtstreeks terecht komt in qua niveau passende banen.

De meerderheid start de loopbaan in functies waarvoor de eigen of een verwante opleidingsrichting is vereist en werkt vier jaar later (nog steeds) in functies die aansluiten bij de gevolgde opleidingsrichting. Een op de tien afgestudeerden (8\%) start de loopbaan weliswaar in qua richting aansluitende functies, maar gaat na verloop van tijd meer algemene functies uitoefenen waarvoor de eigen of een verwante opleidingsrichting niet specifiek is vereist.

Tijdens de eerste jaren van de loopbaan neemt het loon fors toe (gemiddeld met zo'n fl. 1.600 bruto per maand in vier jaar tijd). Ook de loonsverschillen tussen oudstudenten nemen tijdens de eerste vijf jaar na het afstuderen fors toe.

Gaandeweg de beroepsloopbaan neemt het aandeel van leidinggevenden fors toe, en wel van $15 \%$ na anderhalf jaar naar $36 \%$ na vijfeneenhalf jaar.

\section{Succesbepalende factoren bij de loopbaan}

Met behulp van aanvullende analyses is eerst nagegaan welke invloed persoonskenmerken en kwalificatiekenmerken hebben op de kwaliteit van het werk in de intredebaan. Gegeven de invloed van persoonskenmerken en kwalificatiekenmerken is vervolgens nagegaan welk effect kenmerken van de intredebaan en loopbaankenmerken hebben op de kwaliteit van het werk dat oudstudenten gaandeweg hun loopbaan verwerven. Hierbij zijn de volgende indicatoren van de kwaliteit van het werk in de intredebaan en de latere baan geanalyseerd": het niveau van de baan, het leidinggevend karakter van de baan en de hoogte van het loon.

De kwaliteit van het werk, zoals deze zich zo'n vijf jaar na het afstuderen heeft

1. Aangezien vrijwel alle oudstudenten op het moment van de laatste meting betaald-werken, is geen analyse verricht van de kans op betaald werk.

iv 
uitgekristalliseerd, blijkt niet alleen samen te hangen met het volgen van additionele opleidingen na het afstuderen maar ook met de stabiliteit van de loopbaan (het aantal banen dat men na het afstuderen heeft gehad).

De kwaliteit van het latere werk is daarnaast afhankelijk van de kwaliteit van de baan waarin men de loopbaan is gestart (niveau van het werk en hoogte van het loon). Hierbij kunnen drie mechanismen werkzaam zijn: het zoekgedrag van oudstudenten (die alleen van baan veranderen indien zij zich kunnen verbeteren), het selectiegedrag van latere werkgevers (die een baankenmerk, namelijk het loon in de intredebaan gebruiken als indicator voor een persoonskenmerk, namelijk het productieve potentieel van de sollicitant) en de niet-gemeten individuele productiviteit van afgestudeerden. Wat het laatste betreft, bestaat wellicht een onderscheid tussen produktievere afgestudeerden, die erin slagen om goede intredebanen te bemachtigen en gaandeweg hun loopbaan leidinggevend werk en een hoog loon te verwerven, en minder produktieve afgestudeerden bij wie dit niet het geval is. Opvallenderwijs blijken studenten die langer over hun studie doen de produktievere starters te zijn. Wellicht gaat hier de 'human capital' theorie op, die stelt dat de productiviteit en daarmee het loon stijgt naarmate men langer onderwijs volgt (onder de veronderstelling dat een langere studieduur ook impliceert dat men meer dan het strikt vereiste aantal vakken heeft gelopen).

\section{Afstemming tussen opleiding en later werk}

Naast ontwikkelingen in de loopbaan van oudstudenten is in dit rapport nagegaan welke specifieke kwalificaties voor hen van belang zijn bij de uitoefening van het werk dat zij gaandeweg de loopbaan verrichten en in hoeverre deze kwalificaties voldoende aan bod zijn gekomen tijdens hun opleiding aan de UM.

\section{Belang van kwalificaties voor het latere werk}

Gebleken is dat de juiste persoonseigenschappen door oudstudenten het vaakst van belang worden geacht voor het goed kunnen functioneren in het werk. Vaardigheden en kennis-items worden door de bank genomen iets minder belangrijk gevonden.

In de analyses van het belang van kwalificaties voor de latere beroepsuitoefening is onder meer naar voren gekomen dat:

- vrouwen persoonseigenschappen belangrijker vinden dan mannen;

- oudstudenten geneeskunde een groter belang toekennen aan vakkennis dan oudstudenten beleid en beheer van gezondheidszorgvoorzieningen en Nederlands recht, terwijl schriftelijke vaardigheden voor hen relatief onbelangrijk zijn;

- in de non-profit sector meer waarde wordt gehecht aan schriftelijke vaardigheden dan in de profit sector;

- degenen die een leidinggevende functie uitoefenen managementvaardigheden 
belangrijker vinden dan degenen die niet-leidinggevend werk verrichten;

- oudstudenten met werk dat aansluit bij hun opleidingsrichting vakkennis belangrijker vinden dan oudstudenten die buiten hun 'eigen' opleidingssector werken.

\section{Gewenste aandacht voor kwalificaties}

Discrepanties tussen het belang van kwalificaties voor de beroepsuitoefening en de aandacht die deze tijdens de opleiding hebben gekregen, manifesteren zich door de bank genomen sterker bij vaardigheden en in mindere mate kennisaspecten dan bij persoonseigenschappen.

In de analyses van de aandacht die kwalificaties tijdens de opleiding hebben gekregen, is met betrekking tot de aan de UM gevolgde opleidingsrichting naar voren gekomen dat oudstudenten beleid en beheer van gezondheidszorgvoorzieningen van mening zijn dat managementvaardigheden en vakspecifieke methoden en technieken meer aandacht moeten krijgen tijdens de opleiding. Oudstudenten geneeskunde zouden graag zien dat in de opleiding meer aandacht wordt besteed aan kennis van computerprogrammatuuur en informatica. Juristen vinden dat schriftelijk presenteren minder aandacht moet krijgen en oudstudenten verplegingswetenschap vinden dat aan vreemde talen minder aandacht moet worden besteed dan thans het geval is.

Naarmate men langer geleden is afgestudeerd en bijgevolg verder met de beroepsloopbaan is gevorderd, vindt men dat managementvaardigheden in de opleiding meer aandacht zouden moeten krijgen.

De gewenste aandacht voor kwalificaties hangt ook samen met het soort organisatie waarin men werkt. Zo vinden oudstudenten die werken in kleinere organisaties dat in de opleiding meer aandacht zou moeten worden besteed aan kwalificaties als aanpassingsvermogen/flexibiliteit/improvisatievermogen, stressbestendigheid/omgaan met onzekerheid en zelfstandigheid/initiatieven nemen.

Ook het soort functies waarin men werkt is van invloed op de aandacht die men wenst voor bepaalde kwalificaties. Zo zijn oudstudenten met functies die aansluiten bij het niveau van de gevolgde opleiding van mening dat aan managementvaardigheden best wat minder aandacht kan worden besteed.

De gewenste aandacht voor kwalificaties wordt tot slot bepaald door het belang dat bepaalde kwalificaties hebben voor de beroepsuitoefening. Naarmate kwalificaties die verband houden met persoonlijkheid belangrijker zijn voor een goede functievervulling, vindt men dat in de opleiding meer aandacht moet worden besteed aan schriftelijk presenteren, managementvaardigheden en aan kwalificaties als aanpassingsvermogen/flexibiliteit/improvisatievermogen, stressbestendigheid/omgaan met 
onzekerheid en zelfstandigheid/initiatieven nemen. Naar de mening van oudstudenten die functies uitoefenen waarbij managementvaardigheden belangrijk zijn, moet in de opleiding meer aandacht worden besteed aan managementvaardigheden, de beheersing van vreemde talen en kennis van computerprogrammatuuur en informatica. Oudstudenten met functies waarbij het met name gaat om vakkennis wensen dat aan vakspecifieke methoden en technieken meer aandacht wordt besteed. Oudstudenten met functies waarin schriftelijke vaardigheden belangrijk zijn, vinden dat schriftelijk presenteren best wat meer aandacht zou mogen krijgen tijdens de opleiding.

\section{PGO-voordeel}

Naar de mening van de oudstudenten is probleemgestuurd onderwijs het sterkst in het stimuleren van de volgende persoonseigenschappen: zelfstandigheid/initiatieven nemen en aanpassingsvermogen/flexibiliteit/improvisatievermogen. Bovendien wordt een voordeel van $P G O$ ervaren bij het verwerven van vaardigheden als mondelinge presentatie, onderhandelingstechnische vaardigheden, contacten leggen/onderhouden met cliënten, analytische/diagnostische/onderzoeksvaardigheden, pedagogischdidactische vaardigheden, plannen/coördineren/organiseren van activiteiten en de praktische toepassing van kennis.

\section{Ontwikkelingen in de transitie van studie naar werk}

Vanwege de omvangrijke gemiddelde jaarlijkse groei van het aantal afgestudeerden was de eerste helft van de jaren negentig niet de meest optimale periode om de arbeidsmarkt te betreden. Zo schommelt de werkloosheid onder afgestudeerden van de UM in deze periode tussen zeven en tien procent. In 1995 is evenwel verbetering in deze situatie gekomen: de werkloosheid daalde aanzienlijk. De zekerheid van het werk is in de jaren $1992 \mathrm{t} / \mathrm{m} 1994$ licht afgenomen. In 1995 is ook hierin verbetering gekomen: het aandeel van vaste aanstellingen is sterk toegenomen.

Tegenover de in 1995 aanzienlijk gedaalde werkloosheid en sterk toegenomen baanzekerheid staat dat de kans op een baan in het eigen beroependomein, na een sterke toename in 1994, het laatste jaar licht is gedaald. De meest opvallende ontwikkeling vormt evenwel het over de gehele periode 1991-1995 gestaag toenemende aandeel van afgestudeerden die uitwijken naar functies beneden hun opleidingsniveau.

Verder is naar voren gekomen dat in de jaren $1992 \mathrm{t} / \mathrm{m} 1994$ steeds meer afgestudeerden van de UM buiten Limburg zijn gaan werken. Vanaf 1994 stabiliseert het aandeel van zowel de provincie Limburg als de rest van Nederland in de werkgelegenheid van Maastrichtse afgestudeerden. 


\section{Inleiding}

\subsection{Opzet Arbeidsmarktscanner UM}

Het project Arbeidsmarktscanner UM behelst een langlopend onderzoek naar de arbeidsmarktpositie en loopbaanontwikkeling van oudstudenten van de Universiteit Maastricht (UM). Hierbij worden de alumni voor de eerste keer circa anderhalfjaar na het afstuderen schriftelijk bevraagd met behulp van een basisvragenlijst (de basismeting of $t+1$ meting). In de oorspronkelijke projectopzet werden zij vervolgens jaarlijks schriftelijk geënquêteerd middels een zogeheten jaarvragenlijst, waarmee zij mutaties in de loopbaan konden doorgeven (de mutatiemeting). Vanaf 1994 vinden de mutatiemetingen niet langer jaarlijks plaats.

In de nieuwe projectopzet, die vanaf 1994 geldt, vinden jaarlijks twee integrale schriftelijke enquêtes plaats: de basismeting onder de afgestudeerden van het voorgaande jaar ( $\mathrm{t}+1$ meting) en de loopbaanmeting onder oud-studenten die zo' $\mathrm{n}$ vijfeneenhalf jaar geleden zijn afgestudeerd $(t+5$ meting). Het voornemen bestaat om deze twee metingen met ingang van 1998 uit te breiden met een derde meting onder degenen die tien jaar geleden zijn afgestudeerd $(t+10$ meting). De basismeting is gericht op het in kaart brengen van de arbeidsmarktintrede van afgestudeerden. Deze meting wordt jaarlijks gehouden in de maanden oktober-januari onder alle afgestudeerden van het daaraan voorafgaande jaar, hetgeen neerkomt op een tot anderhalf jaar na het afstuderen (afhankelijk van de maand waarin men is afgestudeerd en de maand waarin men de vragenlijst heeft ingevuld). De enquête geeft aldus informatie over de startfuncties van de afgestudeerden. De gehanteerde vragenlijst bevat vragen over de persoon, de afgesloten opleiding, de vooropleiding, de eventuele werk- en bestuurservaring vóór het afstuderen, de belangrijkste activiteiten na het afstuderen tot het moment van enquêteren, de huidige arbeidsmarktpositie, eventueel gevolgd onderwijs na het afstuderen en, bij betaald-werkenden, enkele kenmerken van de huidige functie en van de organisatie waarin men werkzaam is alsmede vragen over de aansluiting van de genoten opleiding op de beroepspraktijk.

Zo'n vijf jaar na het afstuderen worden de oudstudenten opnieuw schriftelijk geenquêteerd met de zogeheten loopbaanvragenlijst. Evenals de basismeting bevat de loopbaanmeting vragen over de huidige arbeidsmarktpositie, eventueel verder onderwijs dat men heeft gevolgd en, bij betaald-werkenden, enkele kenmerken van de huidige functie en van de organisatie waarin men werkzaam is. In beide metingen sluiten de definitie en classificatie van de variabelen waar mogelijk aan bij de gangbare omschrijvingen en indelingen die worden gehanteerd door het Centraal Bureau voor de Statistiek (CBS).

Tot nu toe heeft de onderzoekspopulatie van de Arbeidsmarktscanner UM bestaan 
uit degenen die een doctoraal-getuigschrift hebben behaald aan de Faculteit der Gezondheidswetenschappen (FdGW), de Faculteit der Rechtsgeleerdheid (FdR) of de Faculteit der Economische Wetenschappen en Bedrijfskunde (FdEWB), alsmede degenen die aan de Faculteit der Geneeskunde (FdG) voor het basisartsexamen zijn geslaagd. In de basismeting die thans plaatsvindt, is ook de eerste lichting afgestudeerden van de Faculteit der Cultuurwetenschappen vertegenwoordigd.

In dit rapport worden resultaten gepresenteerd van de eind 1995/begin 1996 gehouden basismeting onder afstudeercohort ' 94 en van de voorjaar 1996 gehouden t+5 meting onder degenen die in 1990 zijn afgestudeerd. De resultaten van de basismeting 1995/96 worden vergeleken met die van de vier voorgaande basismetingen, zodat ontwikkelingen met betrekking tot de transitie van studie naar werk in de eerste helft van de jaren negentig kunnen worden getraceerd. Voor een overzicht van de overige rapportages met betrekking tot afstudeercohort '94 en eerdere cohorten wordt verwezen naar bijlage 1.

De resultaten van de begin 1996 gehouden $t+5$ meting onder cohort ' 90 worden vergeleken met die van de in 1991/92 gehouden $t+1$ meting onder cohort '90, zodat ontwikkelingen in de loopbaan van dit cohort in kaart kunnen worden gebracht. Daarnaast worden resultaten gepresenteerd van de in 1993 gehouden mutatiemeting 'oude stijl', waarin eenmalig vragen betreffende de inhoudelijke afstemming tussen opleiding en werk aan de orde zijn gesteld. In bijlage 1 is een overzicht opgenomen van de rapportages die tot nu toe over de metingen in het kader van de arbeidsmarktscanner zijn uitgebracht.

\subsection{Leeswijzer}

Hoofdstuk 2 gaat in op de beginfase, dat wil zeggen de eerste vijf jaar, in de beroepsloopbaan van de in 1990 afgestudeerde oudstudenten van de UM (voor een beschrijving van de wijze waarop hun transitie van studie naar werk is verlopen, wordt verwezen naar Ramaekers en Heijke, $\left.1993^{2}\right)$. Daartoe wordt eerst de omvang van zowel de geografische mobiliteit als de baanmobiliteit geschetst. Vervolgens wordt ingegaan op de deelname aan post-doctoraal onderwijs. Daarna worden de ontwikkelingen die zich in de beroepsloopbaan hebben voorgedaan in kaart gebracht door de arbeidsmarktpositie zo'n anderhalf jaar na het afstuderen te vergelijken met de arbeidsmarktpositie die men bij de loopbaanmeting, zo'n vijfeneenhalf jaar na het afstuderen, inneemt. Dit gebeurt aan de hand van de indicatoren kans op werk, zekerheid van het werk, niveau van het werk, richting van het werk, leidinggeven en loon.

2. Ramaekers, G.W.M., J.A.M. Heijke (1993), Arbeidsmarktscanner Rijksuniversiteit Limburg: Basismeting cohort '90, ROA-R-1993/1, Researchcentrum voor Onderwijs en Arbeidsmarkt, Maastricht. 
In hoofdstuk 3 wordt nagegaan welke invloed persoonskenmerken, kwalificatiekenmerken, kenmerken van de intredebaan en loopbaankenmerken uitoefenen op de arbeidsmarktpositie die oudstudenten gaandeweg hun loopbaan verwerven. Hiervoor zijn gegevens gebruikt van de in 1990 gehouden retrospectieve basismeting onder de afstudeercohorten '86-'88 en de in 1993 gehouden mutatiemeting waaraan deze cohorten ook hebben deelgenomen. Voor een beschrijving van de wijze waarop de eerste fase in de beroepscarrière van deze cohorten is verlopen, wordt verwezen naar Ramaekers, $1990^{3}$.

Het thema van hoofdstuk 4 vormt de inhoudelijke aansluiting tussen de genoten opleiding en de eisen die de latere beroepspraktijk stelt. Hierbij is gebruik gemaakt van gegevens van de mutatiemeting 1993, waarin eenmalig vragen betreffende de inhoudelijke afstemming tussen opleiding en later werk zijn opgenomen. Eerst wordt ingegaan op het belang dat verschillende kwalificaties hebben voor een goede uitoefening van de functie die men zo'n vijf jaar na het afstuderen vervult en de (loop)baankenmerken die hierbij een rol spelen. Vervolgens wordt nagegaan of de aandacht die in het Maastrichtse onderwijs is besteed aan de kennis en vaardigheden die voor een goede beroepsuitoefening zijn vereist naar de mening van oudstudenten voldoende is geweest en welke factoren bij hun mening een rol spelen.

Tot slot wordt in hoofdstuk 5 aan de hand van een aantal indicatoren (kans op werk, zekerheid van het werk, niveau en richting van het werk en werkregio) geschetst hoe de transitie van studie naar werk in de eerste helft van de jaren negentig is verlopen. Daartoe worden resultaten van de meest recente basismeting, namelijk de eind 1995-begin 1996 uitgevoerde basismeting onder afstudeercohort '94 vergeleken met resultaten uit vier eerdere basismetingen onder achtereenvolgens afstudeercohort '90, '91, 92 en '93.

3. Ramaekers, G.W.M. (1990), Arbeidsmarktscanner Rijksuniversiteit Limburg. Afgestudeerden januari 1996 - juni 1988. Verslag ten behoeve van het College van Bestuur, Researchcentrum voor Onderwijs en Arbeidsmarkt, vertrouwelijke rapportage. 
$\ldots \ldots$ 


\section{Ontwikkeling loopbaan cohort '90}

\subsection{Respons op loopbaanmeting 1996}

Dit hoofdstuk schetst de ontwikkelingen in de loopbaan van afstudeercohort ' 90 aan de hand van de geografische- en baanmobiliteit, de deelname aan vervolgopleidingen en de veranderingen in de kans op werk en kwaliteit van het werk. Alvorens in te gaan op de ontwikkelingen die zich in de loopbaan van afstudeercohort '90 hebben voorgedaan, wordt eerst een beeld geschetst van de mate waarin de betreffende oudstudenten aan de basis- en $t+5$ meting hebben meegedaan.

Tabel 2.1 geeft achtereenvolgens in absolute en relatieve getallen een beeld van de mate waarin de 510 oudstudenten die in 1990 zijn afgestudeerd aan de basis- en $\mathrm{t}+5$ meting hebben meegedaan. De tabel laat zien dat de respons op de basismeting (78\%) hoger is dan op de $t+5$ meting (52\%). Van de in totaal 246 non-respondenten op de $t+5$ meting hebben er 31 (13\%) niet meegedaan omdat van hen de vragenlijst retour werd ontvangen met de vermelding 'verhuisd, nieuw adres onbekend' en het gewijzigde adres niet meer kon worden achterhaald. Overigens is de deelname aan de $t+5$ meting onder economen $(65 \%)$ en oudstudenten geneeskunde $(56 \%)$ hoger dan onder gezondheidswetenschappers (49\%) en juristen (47\%). Tabel 2.1 laat verder zien dat een op zes oudstudenten aan geen van beide metingen heeft meegedaan.

Tabel 2.1

Respons op de basismeting 1991/1992 en t+5 meting 1996, cohort '90

\begin{tabular}{lrrrrr}
\hline & FdG & FdGW & FdR & FdEWB & UM totaal \\
\hline $\begin{array}{l}\text { Deelgenomen aan: } \\
\text { - alleen basismeting }\end{array}$ & 35 & 63 & 47 & 13 & 158 \\
- alleen $t+5$ meting & 5 & 3 & 14 & 3 & 25 \\
- beide metingen & 59 & 81 & 64 & 35 & 239 \\
- geen van beiden & 14 & 27 & 40 & 7 & 88 \\
Totaal $N$ & 113 & 174 & 165 & 58 & 510 \\
Deelgenomen aan: & & & & & \\
- alleen basismeting & $31 \%$ & $36 \%$ & $28 \%$ & $22 \%$ & $31 \%$ \\
- alleen $t+5$ meting & $4 \%$ & $2 \%$ & $8 \%$ & $5 \%$ & $5 \%$ \\
- beide metingen & $52 \%$ & $47 \%$ & $39 \%$ & $60 \%$ & $47 \%$ \\
- geen van beiden & $12 \%$ & $16 \%$ & $24 \%$ & $12 \%$ & $17 \%$ \\
Totaal \% & $100 \%$ & $100 \%$ & $100 \%$ & $100 \%$ & $100 \%$ \\
\hline
\end{tabular}

Aangezien $47 \%$ van de oudstudenten van cohort '90 aan beide metingen heeft meegedaan, kunnen ontwikkelingen in de loopbaan bij ongeveer de helft van dit cohort in kaart worden gebracht. De cijfers in dit hoofdstuk hebben derhalve uitslui- 
tend betrekking op de oudstudenten die aan beide metingen hebben meegedaan. Overigens is de deelname aan beide metingen het hoogst onder economen en het laagst onder juristen. Dit impliceert dat economen in de resultaten zijn oververtegenwoordigd en juristen zijn ondervertegenwoordigd.

\subsection{Mobiliteit na afstuderen}

\section{Baanmobiliteit}

In de $t+5$ enquête is gevraagd om de periodes na het afstuderen aan te geven waarin men bij verschillende werkgevers betaalde arbeid heeft verricht (exclusief militaire of vervangende dienst, doch inclusief de huidige werkgever). Uitzendperiodes moesten hierbij afzonderlijk worden meegeteld. Tabel 2.2 geeft een beeld van het aantal werkgevers waarbij men heeft gewerkt. Zo'n vijfeneenhalf jaar na afstuderen blijkt ruim $90 \%$ al eens van werkgever te zijn veranderd. De grootste groep is op dat moment bij de tweede werkgever in dienst. Overigens vindt de meeste baanmobiliteit in de eerste anderhalf jaar na afstuderen plaats: in deze periode verandert $43 \%$ van werkgever (zie Ramaekers en Heijke ${ }^{4}$, blz. 20). Van alle oudstudenten zijn afgestudeerden geneeskunde in arbeidsmarkttermen gesproken het meest mobiel: vijfeneenhalf jaar na afstuderen hebben de meeste oudstudenten geneeskunde al vier of meer werkgevers gehad.

Tabel 2.2

Aantal werkgevers na afstuderen, cohort ' 90

\begin{tabular}{lrrrrr}
\hline & FdG & FdGW & FdR & FdEWB & UM totaal \\
\hline 1 werkgever & $5 \%$ & $10 \%$ & $6 \%$ & $18 \%$ & $9 \%$ \\
2 werkgevers & $19 \%$ & $48 \%$ & $57 \%$ & $53 \%$ & $44 \%$ \\
3 werkgevers & $21 \%$ & $24 \%$ & $27 \%$ & $21 \%$ & $24 \%$ \\
$>3$ werkgevers & $55 \%$ & $18 \%$ & $10 \%$ & $9 \%$ & $24 \%$ \\
Totaal n (= 100\%) & 58 & 79 & 63 & 34 & 234 \\
\hline
\end{tabular}

\section{Geografische mobiliteit}

Met betrekking tot de werkregio van afgestudeerden van de UM kan een onderscheid worden gemaakt tussen de regionale arbeidsmarkt (de provincie Limburg), de landelijke arbeidsmarkt (de overige provincies) en het buitenland. Tabel 2.3 geeft een beeld van de werkregio waarin afstudeercohort ' 90 de loopbaan is gestart. Naar voren komt dat ongeveer evenveel oudstudenten hun loopbaan starten op de

4. Ramaekers, G.W.M., J.A.M. Heijke (1993), Arbeidsmarktscanner Rijksuniversiteit Limburg: Basismeting cohort '90, ROA-R-1993/1, Researchcentrum voor Onderwijs en Arbeidsmarkt, Maastricht. 
regionale arbeidsmarkt (47\%) als op de landelijke arbeidsmarkt $(48 \%)$. Een op iedere twintig afgestudeerden start de loopbaan in het buitenland. Verder laat tabel 2.3 zien dat juristen relatief vaak de loopbaan starten op de regionale arbeidsmarkt, gezondheidswetenschappers op de landelijke arbeidsmarkt en oudstudenten geneeskunde in het buitenland.

In tabel 2.3 staat ook vermeld waar deze oudstudenten zo'n vijfeneenhalf jaar na het afstuderen werkzaam zijn. Naar voren komt dat niemand van degenen die aan beide metingen hebben meegedaan, ten tijde van de $t+5$ meting in het buitenland werkzaam is. Hierbij zal een rol spelen dat vooral bij de afgestudeerden die in het buitenland blijven werken (en van wie het het buitenlands adres tussentijds is gewijzigd) het actuele adres niet kan worden achterhaald. Verder komt naar voren dat het belang van de landelijke arbeidsmarkt voor de werkgelegenheid gaandeweg de loopbaan toeneemt.

Tabel 2.3

Werkregio ten tijde van de basismeting en $t+5$ meting, cohort ' 90

\begin{tabular}{|c|c|c|c|c|c|}
\hline & FdG & FdGW & FdR & FdEWB & UM totaal \\
\hline $\begin{array}{l}\text { Werkregio na } 1,5 \text { jaar: } \\
-\quad \text { Limburg } \\
-\quad \text { overig Nederland } \\
-\quad \text { buitenland }\end{array}$ & $\begin{array}{r}49 \% \\
42 \% \\
9 \%\end{array}$ & $\begin{array}{r}30 \% \\
67 \% \\
3 \%\end{array}$ & $\begin{array}{r}68 \% \\
29 \% \\
2 \%\end{array}$ & $\begin{array}{r}52 \% \\
44 \% \\
4 \%\end{array}$ & $\begin{array}{r}47 \% \\
48 \% \\
5 \%\end{array}$ \\
\hline Totaal n (= $100 \%)$ & 53 & 69 & 41 & 27 & 190 \\
\hline $\begin{array}{l}\text { Werkregio na } 5,5 \text { jaar: } \\
-\quad \text { Limburg } \\
-\quad \text { overig Nederland } \\
-\quad \text { buitenland }\end{array}$ & $\begin{array}{r}52 \% \\
48 \% \\
0 \%\end{array}$ & $\begin{array}{r}29 \% \\
71 \% \\
0 \%\end{array}$ & $\begin{array}{r}51 \% \\
49 \% \\
0 \%\end{array}$ & $\begin{array}{r}62 \% \\
38 \% \\
0 \%\end{array}$ & $\begin{array}{r}45 \% \\
55 \% \\
0 \%\end{array}$ \\
\hline Totaal n $(=100 \%)$ & 50 & 70 & 55 & 29 & 204 \\
\hline $\begin{array}{l}\text { Werkregio na } 5,5 \text { jaar komt } \\
\text { niet overeen met de } \\
\text { werkregio na } 1,5 \text { jaar }\end{array}$ & $27 \%$ & $8 \%$ & $14 \%$ & $21 \%$ & $16 \%$ \\
\hline
\end{tabular}

Tenslotte staat in tabel 2.3 ook vermeld bij hoeveel procent van de oudstudenten de werkregio na vijfeneenhalf jaar niet overeenkomt met de werkregio na anderhalf jaar. Dit blijkt bij $16 \%$ van de oudstudenten het geval te zijn. Oudstudenten geneeskunde en economen lijken, geografisch gezien, wat mobieler te zijn dan gezondheidswetenschappers en juristen. Hierbij dient echter rekening te worden gehouden met het feit dat eventuele tussentijdse veranderingen in werkregio (tussen het moment van de basismeting en het moment van de $t+5$ meting) niet in kaart zijn gebracht.

Er is ook nagegaan waar oudstudenten, die hun loopbaan in een bepaalde werkregio starten vier jaar later werken. Van de oudstudenten die op de regionale arbeids- 
markt starten, werkt $82 \%$ vier jaar later eveneens op de regionale arbeidsmarkt en $18 \%$ op de landelijke arbeidsmarkt. Van de oudstudenten die op de landelijke arbeidsmarkt starten, werkt $88 \%$ vier jaar later eveneens op de landelijke arbeidsmarkt en $12 \%$ op de regionale arbeidsmarkt. Alle oudstudenten die in het buitenland starten, werken vier jaar later in Limburg.

\subsection{Deelname aan post-doctoraal onderwijs}

In de $\mathrm{t}+5$ enquête is aan de oudstudenten gevraagd of zij na het afstuderen nog additioneel eerste fase-onderwijs, een tweede fase-opleiding of een post-doctorale beroepsopleiding hebben gevolgd of nog steeds volgen. In het geval dat zij meerdere opleidingen volgen of hebben gevolgd, gaat het hierbij om de opleiding met het grootste aantal feitelijke studie-uren. Hiervan geeft tabel 2.4 een beeld. Gemeten zo'n vijfeneenhalf jaar na het afstuderen, heeft ruim de helft van de oudstudenten verder onderwijs gevolgd, meestal een post-doctorale beroepsopleiding. Juristen hebben vaker dan andere afgestudeerden additioneel eerste fase-onderwijs gevolgd; gezondheidswetenschappers en economen zijn relatief vaak doorgestroomd naar een tweede fase-opleiding en basisartsen naar een post-doctorale beroepsopleiding.

Tabel 2.4

Gevolgde opleidingen na afstuderen, cohort '90

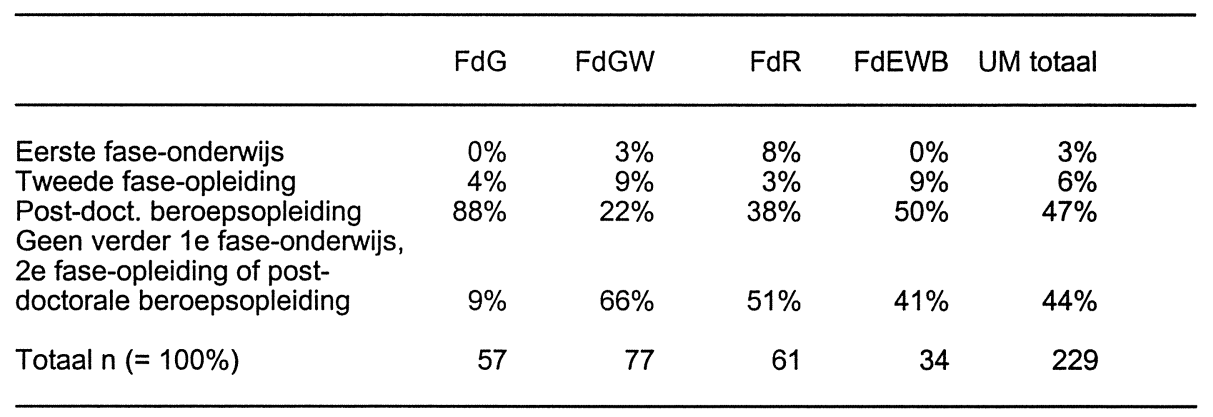

Met betrekking tot de post-doctorale beroepsopleidingen is naar voren gekomen dat van de basisartsen $53 \%$ een opleiding voor medisch specialist is gaan volgen, $19 \%$ de huisartsenopleiding, $11 \%$ een opleiding voor sociaal-geneeskundige en $5 \%$ een andere post-doctorale beroepsopleiding. Van de juristen is $12 \%$ de post-doctorale beroepsopleiding fiscaal recht gaan volgen, eveneens $12 \%$ de post-doctorale beroepsopleiding advocatuur en $15 \%$ een andere post-doctorale beroepsopleiding. Van de economen is $27 \%$ doorgestroomd naar de post-doctorale beroepsopleiding accountancy, $9 \%$ naar de post-doctorale beroepsopleiding voor controller en $15 \%$ naar een andere post-doctorale beroepsopleiding. Gezondheidswetenschappers volgen het minst vaak post-doctoraal beroepsonderwijs. 
In tabel 2.5 staat vermeld met welk resultaat de oudstudenten de tweede faseopleidingen en post-doctorale beroepsopleidingen hebben gevolgd. Het additioneel gevolgd eerste fase-onderwijs wordt buiten beschouwing gelaten aangezien dit geen vervolgonderwijs betreft. Welnu, zo'n vijfeneenhalf jaar na het afstuderen is $41 \%$ van de oudstudenten die een post-doctorale opleiding zijn gaan volgen nog bezig met deze opleiding, de helft $(51 \%)$ heeft deze opleiding voltooid en een op de tien $(9 \%)$ heeft de post-doctorale opleiding voortijdig verlaten. Economen hebben relatief vaak hun vervolgopleiding voltooid. Juristen hebben relatief vaak hetzij de vervolgopleiding voltooid, hetzij de vervolgopleiding voortijdig afgebroken. Basisartsen en gezondheidswetenschappers zijn relatief vaak nog bezig met hun vervolgopleiding.

Een en ander betekent dat zo'n vijfeneenhalf jaar na het afstuderen een kwart (26\%) van de oudstudenten beschikt over formele additionele kwalificaties in de vorm van een voltooide tweede fase-opleiding of post-doctorale beroepsopleiding. Zo'n vijfeneenhalf jaar na het afstuderen hebben oudstudenten geneeskunde $(37 \%)$ en economen $(35 \%)$ vaker een tweede fase-opleiding of post-doctorale beroepsopleiding voltooid dan juristen (25\%) en gezondheidswetenschappers (16\%).

Tabel 2.5

Resultaat waarmee tweede fase-opleidingen en post-doctorale beroepsopleidingen worden gevolgd, cohort ' 90

\begin{tabular}{lrrrrr}
\hline & FdG & FdGW & FdR & FdEWB & UM totaal \\
\hline Opleiding voltooid & $41 \%$ & $52 \%$ & $63 \%$ & $60 \%$ & $51 \%$ \\
Nog bezig met opleiding & $57 \%$ & $44 \%$ & $13 \%$ & $30 \%$ & $41 \%$ \\
Opleiding voortijdig verlaten & $2 \%$ & $4 \%$ & $25 \%$ & $10 \%$ & $9 \%$ \\
Totaal n (= 100\%) & 51 & 23 & 24 & 20 & 118 \\
\hline
\end{tabular}

Overigens waren $12(5 \%)$ van de bevraagde oudstudenten ten tijde van de $t+5$ meting inmiddels tot doctor (dr.) gepromoveerd. Van de 16 bevraagde AIO's hadden er $6(38 \%)$ zo'n vijfeneenhalf jaar na het afstuderen hun proefschrift met een promotie afgerond. Van de 35 bevraagde oudstudenten geneeskunde die een opleiding voor medisch specialist zijn gaan volgen, hadden er $5(14 \%)$ een proefschrift met een promotie afgerond. Eén oudstudent was anders dan als AIO/OIO of medisch specialist tot doctor gepromoveerd.

In de $t+5$ enquête is aan de oudstudenten gevraagd of zij na het afstuderen, naast additioneel eerste fase-onderwijs, tweede fase-opleidingen en post-doctorale beroepsopleidingen, nog andere opleidingen of cursussen hebben gevolgd. Dit blijkt bij bijna de helft (46\%) van de oudstudenten het geval te zijn, namelijk bij $24 \%$ van de oudstudenten geneeskunde, $59 \%$ van de gezondheidswetenschappers, $56 \%$ van de juristen en $33 \%$ van de economen. Dit laat onverlet dat de meerderheid (62\%) van de oudstudenten nog behoefte heeft aan bijscholing. Economen blijken vaker 
behoefte te hebben aan bijscholing ( $86 \%$ ) dan juristen $(62 \%)$, gezondheidswetenschappers $(58 \%)$ en oudstudenten geneeskunde $(52 \%)$.

\subsection{Veranderingen in kans op werk}

In dit rapport worden veranderingen in twee dimensies van de arbeidsmarktpositie in kaart gebracht, namelijk de kans op werk en kwaliteit van het werk. Veranderingen in de kans op werk worden in kaart gebracht aan de hand van de maatschappelijke positie op de twee meetmomenten. Veranderingen in de kwaliteit van het werk tijdens de eerste vijf jaar van de loopbaan worden beschreven aan de hand van vier indicatoren:

- het niveau van het werk op de twee meetmomenten, geïndiceerd door het hebben van een baan waarvoor een opleiding op academisch niveau is vereist;

- de richting van het werk op de twee meetmomenten, geïndiceerd door het hebben van werk waarvoor de eigen- of een daaraan verwante opleidingsrichting is vereist;

- de hoogte van het bruto maandloon op de twee meetmomenten;

- het al dan niet uitoefenen van een leidinggevende functie op de twee meetmomenten.

Tabel 2.6

Maatschappelijke positie ten tijde van de basismeting en $t+5$ meting, cohort ' 90

\begin{tabular}{|c|c|c|c|c|c|}
\hline & FdG & FdGW & $\mathrm{FdR}$ & FdEWB & UM totaal \\
\hline $\begin{array}{ll}\text { Positie na } 1,5 \text { jaar: } \\
\text { - } & \text { betaald werk } \\
\text { - } & \text { student } \\
\text { - } & \text { werkzoekend } \\
\text { - } & \text { dienstplicht } \\
- & \text { andere situatie }\end{array}$ & $\begin{array}{r}91 \% \\
0 \% \\
0 \% \\
7 \% \\
2 \%\end{array}$ & $\begin{array}{r}85 \% \\
6 \% \\
5 \% \\
1 \% \\
3 \%\end{array}$ & $\begin{array}{r}69 \% \\
13 \% \\
12 \% \\
3 \% \\
3 \%\end{array}$ & $\begin{array}{r}89 \% \\
3 \% \\
3 \% \\
6 \% \\
0 \%\end{array}$ & $\begin{array}{r}83 \% \\
6 \% \\
5 \% \\
4 \% \\
2 \%\end{array}$ \\
\hline Totaal n (= 100\%) & 58 & 80 & 61 & 35 & 234 \\
\hline $\begin{array}{ll}\text { Positie na } 5,5 \text { jaar: } \\
\text { - } \quad \text { betaald werk } \\
-\quad \text { studie } \\
-\quad \text { werkzoekend } \\
-\quad \text { dienstplicht } \\
-\quad \text { andere situatie }\end{array}$ & $\begin{array}{r}98 \% \\
0 \% \\
0 \% \\
2 \% \\
0 \%\end{array}$ & $\begin{array}{r}95 \% \\
0 \% \\
0 \% \\
4 \% \\
1 \%\end{array}$ & $\begin{array}{r}95 \% \\
0 \% \\
2 \% \\
0 \% \\
3 \%\end{array}$ & $\begin{array}{r}97 \% \\
0 \% \\
3 \% \\
0 \% \\
0 \%\end{array}$ & $\begin{array}{r}96 \% \\
0 \% \\
1 \% \\
2 \% \\
1 \%\end{array}$ \\
\hline Totaal n (= 100\%) & 58 & 80 & 64 & 35 & 237 \\
\hline
\end{tabular}

De indicator voor de kans op werk betreft de maatschappelijke positie die volgens de respondenten hun dagelijkse situatie ten tijde van de twee metingen het beste weergeeft. Tabel 2.6 geeft hiervan een beeld. De tabel laat zien dat de kans op werk gaandeweg de loopbaan toeneemt: het aandeel van betaald-werkenden stijgt van $83 \%$ na 1,5 jaar naar $96 \%$ na 5,5 jaar en het aandeel van werkzoekenden daalt van 
$5 \%$ na 1,5 jaar naar $1 \%$ na 5,5 jaar. Ook het aandeel van dienstplichtig militairen en oudstudenten met studie als voornaamste bezigheid neemt gaandeweg de loopbaan af. Tabel 2.6 laat verder zien dat de in 1990 afgestudeerde juristen hun aanvankelijke achterstand met betrekking tot de kans op werk zo'n vijfeneenhalf jaar na het afstuderen geheel hebben weggewerkt.

$\mathrm{Er}$ is ook nagegaan welke verschuivingen in maatschappelijke positie zich tussen de twee metingen op het niveau van individuele oudstudenten hebben voorgedaan. Hiervan geeft tabel 2.7 een beeld. Naar voren komt dat alle oudstudenten die zo'n anderhalf jaar na afstuderen werkzoekend of student waren vier jaar later een betaalde baan blijken te hebben.

Tabel 2.7

Verschuivingen in maatschappelijke positie tussen de basismeting en de $t+5$ meting, cohort ' 90

\begin{tabular}{|c|c|c|c|c|c|}
\hline & $\begin{array}{l}\quad \text { Maa } \\
\text { betaald } \\
\text { werk }\end{array}$ & $\begin{array}{l}\text { schappe } \\
\text { studie }\end{array}$ & $\begin{array}{l}\text { positie na } \\
\text { werkzoe- } \\
\text { kend }\end{array}$ & $\begin{array}{l}\text { 1,5 jaar: } \\
\text { dienst- } \\
\text { plicht }\end{array}$ & anders \\
\hline $\begin{array}{l}\text { Maatsch. positie na } 5,5 \text { jaar: } \\
\text { - betaald werk } \\
\text { - studie } \\
\text { - werkzoekend } \\
\text { - dienstplicht } \\
\text { - andere situatie }\end{array}$ & $\begin{array}{r}97 \% \\
0 \% \\
1 \% \\
1 \% \\
2 \%\end{array}$ & $\begin{array}{r}100 \% \\
0 \% \\
0 \% \\
0 \% \\
0 \%\end{array}$ & $\begin{array}{r}100 \% \\
0 \% \\
0 \% \\
0 \% \\
0 \%\end{array}$ & $\begin{array}{r}88 \% \\
0 \% \\
13 \% \\
0 \% \\
0 \%\end{array}$ & $\begin{array}{r}80 \% \\
0 \% \\
0 \% \\
20 \% \\
0 \%\end{array}$ \\
\hline Totaal n (= $100 \%)$ & 193 & 14 & 12 & 8 & 5 \\
\hline
\end{tabular}

\subsection{Veranderingen in kwaliteit van het werk}

Hieronder wordt nagegaan in hoeverre het verdere verloop van de loopbaan samenhangt met het soort baan waarin de loopbaan wordt gestart. Dit gebeurt door de baan ten tijde van de basismeting (zo'n anderhalf jaar na afstuderen) te vergelijken met de baan die men bij de $t+5$ meting heeft (zo'n vijfeneenhalf jaar na afstuderen). Hierbij wordt achtereenvolgens gekeken naar:

- de vereiste opleiding voor het werk, die een indicatie vormt voor het niveau en de richting van het werk;

- de hoogte van het loon;

- het al dan niet leidinggeven.

Niveau van het werk

Bij alle faculteiten, met name bij de FdG en FdEWB, kan worden geconstateerd dat de meerderheid van de afgestudeerden de loopbaan in banen op academisch niveau start en de loopbaan in qua niveau passende banen voortzet. Tabel 2.8 laat zien dat ruim driekwart ( $79 \%$ ) van de oudstudenten die aan beide metingen hebben 
meegedaan de loopbaan start in functies op academisch niveau en zo'n vier jaar later (nog steeds) op academisch niveau werkzaam is. Zeven procent van de afgestudeerden start de loopbaan weliswaar in functies onder hun niveau, maar groeit na verloop van tijd door naar functies die passen bij het niveau van hun academische opleiding. Dit betekent dat $86 \%$ al dan niet via een omweg terecht komt in qua niveau passende banen.

Tabel 2.8

Niveau van het werk ten tijde van de basismeting en $t+5$ meting, cohort ' 90

\begin{tabular}{lrrrrr}
\hline & FdG & FdGW & FdR & FdEWB & UM totaal \\
\hline $\begin{array}{l}\text { Op WO-nivo na 1,5 jaar en } \\
\text { op WO-nivo na 5,5 jaar }\end{array}$ & $98 \%$ & $69 \%$ & $65 \%$ & $81 \%$ & $79 \%$ \\
$\begin{array}{l}\text { Op WO-nivo na 1,5 jaar en } \\
\text { onder WO-nivo na 5,5 jaar }\end{array}$ & $0 \%$ & $5 \%$ & $8 \%$ & $7 \%$ & $4 \%$ \\
$\begin{array}{l}\text { Onder WO-nivo na 1,5 jaar en } \\
\text { onder WO-nivo na 5,5 jaar }\end{array}$ & $0 \%$ & $16 \%$ & $16 \%$ & $7 \%$ & $10 \%$ \\
$\begin{array}{l}\text { Onder WO-nivo na 1,5 jaar en } \\
\text { op WO-nivo na 5,5 jaar }\end{array}$ & $2 \%$ & $10 \%$ & $11 \%$ & $7 \%$ & $7 \%$ \\
\begin{tabular}{l} 
Totaal n (= 100\%) \\
\hline
\end{tabular} & 52 & 62 & 37 & 31 & 182 \\
\hline
\end{tabular}

Bij één op iedere zeven oudstudenten heeft de loopbaan, tenminste wat dit kenmerk betreft, een problematisch verloop te zien gegeven: ofwel men start de loopbaan onder zijn niveau en blijft vooralsnog onder zijn niveau werken $(10 \%)$, óf men start weliswaar in een academische functie maar komt na verloop van tijd onder zijn opleidingsniveau terecht (4\%). Problematische loopbanen doen zich, wat dit aspect betreft, relatief vaak voor onder oudstudenten van de FdGW en FdR.

Bij de meeste $(89 \%)$ oudstudenten komt het niveau van het werk na vijfeneenhalf jaar overeen met het niveau van het werk dat men anderhalf jaar na het afstuderen had. Dit laat onverlet dat $42 \%$ van degenen die de loopbaan starten in een functie onder hun opleidingsniveau vier jaar later zijn doorgegroeid naar een functie die wel past bij het niveau van de genoten opleiding.

\section{Richting van het werk}

In de in 1991 uitgevoerde basismeting onder cohort '90 is aan de betaald-werkende afgestudeerden gevraagd wat de minimale opleidingsvereisten voor de functie zijn. Zij konden hierbij kiezen uit één van de volgende antwoordcategorieën: geen opleidingsvereiste; lager dan $\mathrm{HBO}$-opleiding; tenminste $\mathrm{HBO}$-opleiding; elke academische opleiding; uw of een verwante academische opleiding; uw academische opleiding ongeacht specialisatie; uw academische opleiding met uw specialisatie. 
Deze wijze van vraagstelling impliceert dat in de basismeting onder cohort ' 90 alleen bij banen op academisch niveau een onderscheid kan worden gemaakt tussen banen waarvoor de eigen of een verwante opleidingsrichting is vereist (de antwoordcategorieën: uw of een verwante academische opleiding; uw academische opleiding ongeacht specialisatie; uw academische opleiding met uw specialisatie) aan de ene kant en banen waarbij dit niet het geval is (de antwoordcategorie: elke academische opleiding). In de in 1996 uitgevoerde $t+5$ meting onder cohort ' 90 is de vraag naar de vereiste opleiding gesplitst in een aparte vraag naar het opleidingsniveau dat voor de functie minimaal door de werkgever werd vereist en een aparte vraag naar de opleidingsrichting die voor de functie door de werkgever werd vereist.

Tabel 2.9

Richting van het werk op academisch niveau ten tijde van de basismeting en $\mathrm{t}+5$ meting, cohort '90

\begin{tabular}{lccccc}
\hline & FdG & FdGW & FdR & FdEWB & UM totaal \\
\hline $\begin{array}{l}\text { Eigen richting na 1,5 jaar en } \\
\text { eigen richting na 5,5 jaar }\end{array}$ & $100 \%$ & $77 \%$ & $88 \%$ & $88 \%$ & $89 \%$ \\
$\begin{array}{l}\text { Eigen richting na 1,5 jaar en } \\
\text { andere richting na 5,5 jaar }\end{array}$ & $0 \%$ & $19 \%$ & $8 \%$ & $8 \%$ & $8 \%$ \\
$\begin{array}{l}\text { Andere richting na 1,5 jaar en } \\
\text { andere richting na 5,5 jaar }\end{array}$ & $0 \%$ & $2 \%$ & $4 \%$ & $0 \%$ & $1 \%$ \\
$\begin{array}{l}\text { Andere richting na 1,5 jaar en } \\
\text { eigen richting na 5,5 jaar }\end{array}$ & $0 \%$ & $2 \%$ & $0 \%$ & $4 \%$ & $1 \%$ \\
\begin{tabular}{l} 
Totaal n (= 100\%) \\
\hline
\end{tabular} & 51 & 43 & 24 & 25 & 143 \\
\hline
\end{tabular}

In tabel 2.9 wordt de richting van het werk op academisch niveau ten tijde van de basismeting vergeleken met de richting van het werk op academisch niveau ten tijde van de $t+5$ meting. Hierbij is een onderscheid gemaakt tussen werk waarvoor de eigen of een daaraan verwante opleidingsrichting is vereist (werk in eigen richting) en werk waarvoor dit niet geldt (werk in andere richting). De tabel laat zien dat de overgrote meerderheid van de afgestudeerden de loopbaan start met werk dat aansluit bij de gevolgde opleidingsrichting en vier jaar later nog steeds werk verricht dat past bij de opleidingsrichting. Een op de tien afgestudeerden (8\%) start de loopbaan weliswaar in werk dat aansluit bij de gevolgde opleidingsrichting maar gaat na verloop van tijd functies uitoefenen die wat verder afstaan van de opleidingsrichting die men gevolgd heeft. Dit is met name bij gezondheidswetenschappers relatief vaak het geval.

Loon

In de in 1991 uitgevoerde basismeting onder cohort '90 is aan de betaald-werkende 
afgestudeerden gevraagd om voor hun hoofdfunctie de hoogte van het bruto maandloon bij een volledige werkweek aan te geven (exclusief eventuele toeslagen vanwege overwerk, dertiende maand, vakantiegeld en dergelijke). In de in 1996 gehouden $t+5$ meting is aan de betaald-werkende afgestudeerden achtereenvolgens voor de hoofdfunctie en eventuele nevenfunctie(s) gevraagd naar de hoogte van het bruto maandloon inclusief eventuele provisie en fooien en eventuele toeslagen voor ploegendienst of onregelmatig werk, doch exclusief inkomsten uit overwerk en bijzondere uitkeringen zoals $13 \mathrm{e}$ maand, winstdeling, gratificatie, kinderbijslag, vakantiegeld, vergoeding voor reiskosten/kleding en dergelijke.

Tabel 2.10 geeft een beeld van het bruto maandloon bij een volledige werkweek, gemeten zo'n anderhalf jaar na afstuderen en het bruto maandloon, omgerekend naar een volledige (dit wil zeggen 40-urige) werkweek, gemeten zo'n vijfeneenhalf jaar na afstuderen. De resultaten laten zien dat het loon gedurende de eerste jaren van de loopbaan fors toeneemt (gemiddeld met zo'n fl. 1.600 bruto per maand in vier jaar tijd). Deze toename is vooral onder economen zeer aanzienlijk. Niet alleen het loon maar ook de loonsverschillen nemen tijdens de eerste vijf jaar na afstuderen fors toe. Vooral onder economen en oudstudenten geneeskunde beginnen zich duidelijke loonsverschillen af te tekenen.

Tabel 2.10

Gemiddeld bruto maandloon in guldens bij een volledige werkweek ten tijde van de basismeting en $\mathrm{t}+5$ meting, cohort ' 90

\begin{tabular}{lrrrrr}
\hline & FdG & FdGW & FdR & FdEWB & UM totaal \\
\hline Loon na 1,5 jaar & 4.100 & 3.650 & 3.300 & 3.600 & 3.690 \\
Standaardafwijking & 1.230 & .980 & .530 & .850 & 1.000 \\
Loon na 5,5 jaar & 5.870 & 4.860 & 4.700 & 6.400 & 5.310 \\
Standaardafwijking & 2.790 & 1.330 & 1.110 & 2.070 & 1.970 \\
Gemiddelde stijging & 1.770 & 1.210 & 1.400 & 2.800 & 1.620 \\
\hline
\end{tabular}

Afgerond op 10 gulden.

\section{Leidinggeven}

In zowel de basismeting als de $t+5$ meting onder cohort ' 90 is aan de betaaldwerkende oudstudenten gevraagd of men een leidinggevende functie heeft en, zo ja, aan hoeveel mensen men leiding geeft. Het antwoord op deze vraag geeft weliswaar een indicatie van de mate waarin men leiding geeft maar niet van het niveau waarop leiding wordt gegeven, dat wil zeggen van de opleidingsniveaus van de mensen waaraan men leiding geeft.

Tabel 2.11 geeft een beeld van de mate waarin oudstudenten gaandeweg hun beroepsloopbaan doorgroeien naar leidinggevende functies. De tabel laat zien dat 
het aandeel van leidinggevenden fors toeneemt, van $15 \%$ na anderhalf jaar naar $36 \%$ na vijfeneenhalf jaar. De grootste groep oudstudenten (58\%) start de loopbaan echter in een niet-leidinggevend functie en oefent zo'n vijfeneenhalf jaar na het afstuderen (nog steeds) geen leidinggevende functie uit. Ruim eenderde $(36 \%)$ is dan wel leidingevend werkzaam na de loopbaan al $(9 \%)$ dan niet $(27 \%)$ in een leidinggevende functie te zijn gestart. Ook wat dit aspect van de loopbaan betreft, is de functie waarin de loopbaan wordt gestart in hoge mate bepalend voor de functie die men gaandeweg de loopbaan inneemt (qua leidinggeven verschilt 'slechts' bij $33 \%$ van de oudstudenten de latere functie van de intredefunctie).

Tabel 2.11

Leidinggeven ten tijde van de basismeting en $t+5$ meting, cohort ' 90

\begin{tabular}{lccccc}
\hline & FdG & FdGW & FdR & FdEWB & UM totaal \\
\hline $\begin{array}{l}\text { Geen leiding na 1,5 jaar en } \\
\text { geen leiding na 5,5 jaar }\end{array}$ & $55 \%$ & $62 \%$ & $62 \%$ & $52 \%$ & $58 \%$ \\
$\begin{array}{l}\text { Geen leiding na 1,5 jaar en } \\
\text { wel leiding na 5,5 jaar }\end{array}$ & $32 \%$ & $21 \%$ & $21 \%$ & $39 \%$ & $27 \%$ \\
$\begin{array}{l}\text { Wel leiding na 1,5 jaar en } \\
\text { wel leiding na 5,5 jaar }\end{array}$ & $4 \%$ & $11 \%$ & $10 \%$ & $10 \%$ & $9 \%$ \\
$\begin{array}{l}\text { Wel leiding na 1,5 jaar en } \\
\text { geen leiding na 5,5 jaar }\end{array}$ & $9 \%$ & $6 \%$ & $8 \%$ & $0 \%$ & $6 \%$ \\
\begin{tabular}{l} 
Totaal n (= 100\%) \\
\hline
\end{tabular} & 47 & 63 & 39 & 31 & 180 \\
\hline
\end{tabular}




\section{Analyse van de kwaliteit van het latere werk}

Met behulp van aanvullende analyses op loopbaangegevens van afstudeercohort '90 is eerst nagegaan welke invloed persoonskenmerken en kwalificatiekenmerken hebben op de kwaliteit van de intredebaan. Vervolgens is nagegaan in hoeverre de kwaliteit van de latere baan (zo'n vijfeneenhalf jaar na afstuderen) wordt bepaald door de kwaliteit van de intredebaan, of mede afhangt van persoonskenmerken, kwalificatiekenmerken en kenmerken van de loopbaan. Om te voorkomen dat kenmerken van de latere baan zichzelf gaan verklaren (in het geval dat afgestudeerden niet van baan zijn veranderd waardoor de intredebaan en de latere baan identiek zijn) hebben de analyses alleen betrekking op afgestudeerden die niet langer in hun intredebaan werkzaam zijn.

De volgende indicatoren van de kwaliteit van de intredebaan en de latere baan zijn geanalyseerd ${ }^{5}$ :

- de kans dat voor de functie een opleiding op academisch niveau is vereist (werk op WO-niveau);

- de kans dat de functie leidinggevend is (leidinggevend werk);

- de hoogte van het inkomen uit betaalde arbeid (bruto maandloon) ${ }^{6}$.

Voor de preciese wijze waarop deze te verklaren variabelen zijn gedefinieerd, wordt verwezen naar bijlage 3 .

De resultaten van de schattingen van de kwaliteit van de intredebaan worden in tabel 3.1 weergegeven en van de latere baan in tabel 3.2. Bij een aantal kenmerken is een referentiecategorie opgenomen. De resultaten van de overige categorieën zijn dan gerelateerd aan deze referentiecategorie.

Als verklarende variabelen zijn in iedere schatting van de kwaliteit van de intredebaan steeds twee persoonskenmerken en vijf kwalificatiekenmerken van de respondenten alsmede de duur van de intredewerkloosheid opgenomen. De twee persoonskenmerken betreffen het geslacht en de leeftijd in het jaar van afstuderen. De kwalificaties waarmee afgestudeerden de arbeidsmarkt betreden, hebben betrekking op de genoten vooropleiding, de aan de UM gevolgde opleiding en de studieduur, alsmede op de voor het vakgebied relevante werkervaring en bestuurlijke ervaring die men voor of tijdens de studie aan de UM heeft opgedaan.

In de schattingen van de kwaliteit van de latere baan zijn naast de bovengenoemde verklarende variabelen één additioneel persoonskenmerk, drie kenmerken van de

5. Aangezien vrijwel alle oudstudenten op het moment van de laatste meting betaald-werken $(94 \%)$, is geen analyse verricht van de kans op betaald werk.

6. In de analyse is de logaritme van het bruto maandloon genomen. 
intredebaan en twee loopbaankenmerken opgenomen. Bij het additioneel opgenomen persoonskenmerk gaat het om de huidige gezinssituatie. De drie kenmerken van de intredebaan betreffen het vereiste opleidingsniveau, het al dan niet leidinggevend karakter van de baan en de hoogte van het loon. Bij de twee loopbaankenmerken gaat het om het aantal werkgevers waarbij men sinds het afstuderen heeft gewerkt (inclusief de huidige werkgever) en de vervolgopleidingen die men eventueel heeft afgerond.

Voor deze variabelen zijn dummies geconstrueerd, behoudens voor de leeftijd in jaren (leeftijd), het bruto maandloon (in de intredefunctie bij een volledige werkweek en in de latere functie omgerekend naar een veertigurige werkweek; zie paragraaf 2.5), de duur van de intredewerkloosheid in maanden (duur intredewerkloosheid) en het aantal werkgevers sinds het afstuderen (aantal banen). Met betrekking tot de variabele leeftijd dient te worden vermeld dat vier procent van de steekproef in het jaar van afstuderen ouder was dan 30 jaar. Om te voorkomen dat de relatief hoge leeftijden van deze kleine groep een te zware wissel zouden trekken op analyseresultaten zijn deze dertigplussers buiten de analyses gelaten. Vanwege dezelfde reden is het loon logaritmisch getransformeerd. De dummy-variabelen hebben achtereenvolgens betrekking op geslacht: man; de samenstelling van het huishouden (alleenstaand, gehuwd/samenwonend met kinderen of gehuwd/samenwonend zonder kinderen); het beschikken over een diploma van een opleiding in het hoger onderwijs voordat men aan de UM kwam studeren (HO-vooropleiding); het beschikken over voor het vakgebied relevante betaalde werkervaring, opgedaan vóór of tijdens de studie aan de UM (relevante werkervaring); het beschikken over bestuurlijke ervaring, opgedaan vóór of tijdens de studie aan de UM (bestuurlijke ervaring); de aan de UM gevolgde opleiding: geneeskunde, gezondheidswetenschappen (gez. wet.), Nederlands recht (Ned. recht) en economie; het overschrijden van de nominale studieduur met meer dan één jaar (studieduur); een functie op WO-niveau (werk op WO-niveau); een leidinggevende functie (leidinggevend werk); het nooit gevolgd of voortijdig verlaten hebben van een tweede fase-opleiding/postdoctorale beroepsopleiding (geen vervolgopleiding), het bezig zijn met het volgen van een tweede fase-opleiding/postdoctorale beroepsopleiding (bezig vervolgopleiding) en het afgerond hebben van een tweede fase-opleiding/postdoctorale beroepsopleiding (vervolgopleiding voltooid). In de schattingen fungeerde geneeskunde steeds als referentie voor de gevolgde opleiding, alleenstaand steeds als referentie voor de huidige samenstelling van het huishouden, en geen vervolgopleiding steeds als referentie voor de post-doctorale onderwijskwalificaties. Voor de preciese omschrijving van de dummy-codes wordt verwezen naar bijlage 3 .

Er wordt verondersteld dat de kwaliteit van het werk verschilt naar gelang de formele kwalificaties waarover men door af te studeren beschikt, geïndiceerd door de gevolgde opleiding. Verder wordt verwacht dat discriminatie op basis van geslacht ertoe kan leiden dat vrouwen een slechtere arbeidsmarktpositie hebben dan 
mannen, dat wil zeggen een kleinere kans dan mannen op leidinggevend werk en een hoog loon en vaker dan mannen zijn gedwongen om uit te wijken naar functies beneden het behaalde opleidingsniveau. Vanwege een aantal redenen mag worden verwacht dat jongere afgestudeerden makkelijker kunnen doorgroeien naar betere functies dan ouderen. Jongeren zijn doorgaans flexibeler en kunnen zich daardoor wellicht makkelijker aanpassen aan de specifieke cultuur van de werkorganisatie. Bovendien zullen jongeren wellicht eerder bereid zijn om aanvullende (bedrijfsspecifieke) opleidingen te volgen, aangezien hun investering in aanvullend onderwijs gedurende een groter aantal arbeidsjaren tot een hoger loon zal leiden. Vanuit de werkgever gezien kunnen de in bedrijfsopleidingen geïnvesteerde tijd en kosten, middels de verwachte hogere arbeidsproductiviteit, bij jongeren over een groter aantal arbeidsjaren worden terugverdiend. Daarbij komt dat voor jongeren, vanwege het groter aantal arbeidsjaren dat zij nog voor zich hebben, een flexibeler loopbaanplanning mogelijk is: zij zijn makkelijker in lagere startfuncties inzetbaar om van daaruit, mede door het volgen van bedrijfsspecifieke opleidingen, door te stromen naar hogere functies in de organisatie. Met betrekking tot de gezinssituatie wordt verwacht dat alleenstaanden, omdat zij niet aan een partner en kinderen zijn gebonden, flexibeler zijn om daar te gaan werken waar de kwaliteit van het werk het beste is.

Extra kwalificaties in de vorm van het reeds beschikken over een HO-diploma vóórdat men aan de UM gaat studeren en voor het vakgebied relevante betaalde werkervaring of bestuurlijke ervaring, opgedaan vóór of tijdens de studie aan de UM, maken iemand voor een werkgever aantrekkelijker waardoor de kans op een goede kwaliteit van het werk toeneemt. Hetzelfde geldt voor degenen die slechts weinig tijd nodig hebben gehad om de opleiding te voltooien en degenen die inmiddels een tweede fase-opleiding of postdoctorale beroepsopleiding hebben voltooid.

Verder wordt verwacht dat goede starters, dat wil zeggen afgestudeerden die niet of slechts kort werkloos zijn voorafgaand aan hun eerste baan en de loopbaan starten in goede intredebanen (leidinggevende functie, hoog loon en werk dat qua niveau past bij de genoten opleiding) hun carrière in soortgelijke goede banen zullen voortzetten. Verwacht wordt dat degenen die inmiddels een tweede fase-opleiding of postdoctorale beroepsopleiding hebben voltooid betere banen zullen krijgen omdat zij over meer 'menselijk kapitaal' beschikken. Met betrekking tot degenen die momenteel een tweede fase-opleiding of postdoctorale beroepsopleiding volgen, wordt verwacht dat hun baan vaker vooralsnog niet leidinggevend is, dat hun loon lager is en dat hun werk qua vereist opleidingsniveau passend is. Tot slot wordt verondersteld dat de kans op een goede kwaliteit van het latere werk daalt naarmate de loopbaan onstabieler is, geïndiceerd door het aantal banen dat men inmiddels heeft gehad.

Op basis van de hiervoor genoemde veronderstellingen en de wijze waarop de 
variabelen zijn geoperationaliseerd, worden positieve effecten verwacht voor mannelijk geslacht, HO-vooropleiding, werk- en bestuurlijke ervaring, opgedaan vóór het afstuderen, de kenmerken van de intredebaan alsmede voor het voltooien van een tweede fase-opleiding of postdoctorale beroepsopleiding. Voor leeftijd, andere gezinssituaties dan alleenstaand, studieduur, duur van de intredewerkloosheid en het aantal banen na het afstuderen worden negatieve parametertekens verwacht. Voor degenen die een tweede fase-opleiding of postdoctorale beroepsopleiding volgen, worden negatieve parametertekens verwacht, behoudens bij de kans op werk op WO-niveau.

\section{Kwaliteit van de intredebaan}

De schattingsresultaten in tabel 3.1 laten zien dat de kwaliteit van de intredebaan niet afhangt van het geslacht, de leeftijd, de vooropleiding en de eventuele werkervaring, noch van de snelheid waarmee men werk heeft gevonden. Bij de kwaliteit van de intredebaan speelt wel bestuurlijke ervaring, de gevolgde opleiding en de studieduur een rol. De bestuurlijke ervaring blijkt van invloed te zijn op het leidinggevend karakter van de intredebaan, de gevolgde opleiding op het niveau van de intredebaan en de studieduur op het loon.

\section{Kwaliteit van de latere baan}

De schattingsresultaten in tabel 3.2 laten zien dat de in de analyses opgenomen persoonskenmerken (geslacht, leeftijd en gezinssituatie) niet van invloed zijn op de kwaliteit van het werk dat oudstudenten gaandeweg hun loopbaan verwerven. De kwaliteit van het latere werk wordt evenmin bepaald door de kwalificaties waarmee oudstudenten destijds de arbeidsmarkt hebben betreden, noch door de wijze waarop hun intrede op de arbeidsmarkt destijds is verlopen. De kwaliteit van het latere werk hangt wel samen met enkele kenmerken van de intredebaan en de loopbaan. Zo blijkt het niveau van de intredebaan van invloed te zijn op het niveau van het latere werk. Het vervolgonderwijs en de baanmobiliteit hebben repercussies voor het latere loon. Tot slot blijkt het loon in de intredebaan van invloed te zijn op het leidinggevend karakter en het loon van de latere baan.

Op het effect van de factoren die het verloop van de beroepscarrière mogelijk beïnvloeden zal hieronder achtereenvolgens worden ingegaan.

\section{Effect van persoonskenmerken op de loopbaan}

Een mogelijke discriminatie in het arbeidsproces van vrouwen en oudere afgestudeerden kon in de uitgevoerde analyses niet worden vastgesteld. Het geslacht en de leeftijd blijken geen significant effect te hebben op de kwaliteit van de intredebaan noch op de kwaliteit van het latere werk. Het andere in de analyse opgenomen 
persoonskenmerk, namelijk de latere gezinssituatie, blijkt evenmin van invloed te zijn op de kwaliteit van het (latere) werk. Het verwachte positieve effect van de variabele alleenstaand is dus uitgebleven.

\section{Effect van kwalificatiekenmerken op de loopbaan}

Additioneel 'menselijk kapitaal' in de vorm van een voltooide hogere opleiding voorafgaand aan de universitaire studie of in de vorm van voor het vakgebied relevante werkervaring, opgedaan vóór of tijdens de studie aan de UM, blijkt geen significant effect te hebben op de kwaliteit van de intredebaan en de latere baan.

Conform de verwachting heeft bestuurlijke ervaring, opgedaan vóór of tijdens de studie aan de UM, een positief effect op de kans dat de intredebaan een leidinggevende functie betreft. De kans dat de latere baan eveneens leidinggevend is, hangt evenwel niet samen met het leidinggevend karakter van de intredebaan noch met de vroeger opgedane bestuurlijke ervaring. Gaandeweg de loopbaan gaan blijkbaar andere variabelen een rol spelen bij de kans om door te groeien naar een leidinggevende functie.

De aan de UM gevolgde opleiding blijkt alleen een significant effect te hebben op het niveau van de intredebaan. Vergeleken met basisartsen hebben afgestudeerden van andere opleidingen meer kans om onder hun opleidingsniveau terecht te komen. Zoals eerder is opgemerkt, starten oudstudenten geneeskunde - die in de analyses als referentiegroep fungeerden - vaker dan afgestudeerden van andere opleidingen de loopbaan in banen op academisch niveau. Hierbij speelt een rol dat basisartsen hoofdzakelijk terecht komen in een professionele vakdeelmarkt waar uitsluitend de, per definitie academische opleiding geneeskunde toegang tot verschaft. Gaandeweg de loopbaan groeien echter veel van de afgestudeerden van de andere opleidingen, die de loopbaan onder hun niveau starten, door naar een functie die wel past bij hun opleidingsniveau (zie tabel 2.8). Hierdoor ebt het effect van de gevolgde opleiding weg.

Tegen verwachting gaat overschrijding van de nominale studieduur (waarbij is gecorrigeerd voor leeftijd) samen met een hoger loon in de intredebaan. Onder de veronderstelling dat een langere studieduur ook impliceert dat men meer dan het strikt vereiste aantal vakken heeft gelopen, spoort deze bevinding overigens wel met de 'human capital' theorie, die ervan uitgaat dat de productiviteit en daarmee het loon stijgt naarmate men langer onderwijs volgt.

\section{Effect van intredewerkloosheid op de loopbaan}

De mate van succes waarmee men de arbeidsmarkt betreedt, geoperationaliseerd door de tijd die men nodig heeft gehad om de eerste baan na afstuderen te vinden, 
heeft tenminste bij afstudeercohort '90 geen repercussies gehad voor de kwaliteit van het werk in de eerste baan en de latere baan.

\section{Effect van de intredebaan op de latere baan}

De schattingsresultaten in tabel 3.2 laten zien dat het niveau van het werk en de hoogte van het loon in de intredebaan mede bepalend zijn voor de kwaliteit van het werk, zoals deze zich zo'n vijf jaar na het afstuderen heeft ontwikkeld. Afgestudeerden die hun loopbaan starten in een baan die past bij het niveau van hun opleiding hebben een grotere kans om na vijf jaar nog steeds werk te verrichten dat past bij het niveau van hun opleiding. Verder blijkt dat het leidinggevend karakter van het latere werk alsmede het latere loon mede afhankelijk zijn van het loon dat men in de intredebaan verdiende.

Voor het geconstateerde effect van de intredebaan op de latere baan zijn drie verklaringen mogelijk. In de eerste plaats kan het zoekgedrag van werknemers hierbij een rol spelen. Immers, afgestudeerden zullen alleen genegen zijn van baan te veranderen indien zij zich kunnen verbeteren. Een ander mechanisme dat hier mogelijk werkzaam is, houdt verband met het selectiegedrag door werkgevers. Het feit namelijk dat een sollicitant in de vorige baan veel verdiende kan voor de werkgever een signaal zijn dat de sollicitant in hoge mate over productieve vermogens beschikt. De laatste verklaring is dat er mogelijkerwijs twee soorten afgestudeerden zijn: produktievere afgestudeerden die erin slagen om goede intredebanen te bemachtigen en gaandeweg hun loopbaan leidinggevend werk en een hoger loon te verwerven, en minder produktieve starters bij wie dit niet het geval is. Volgens de laatste verklaring zou niet het leidinggevend karakter van de intredebaan maar de productiviteit van de afgestudeerde, tot uiting komend in een hoog loon in de intredebaan, bepalend zijn voor het leidinggevend karakter van het latere werk.

\section{Effect van loopbaankenmerken op de latere baan}

De kwaliteit van het werk dat oudstudenten zo'n vijf jaar na het afstuderen hebben verworven, wordt niet alleen bepaald door kenmerken van hun intredebaan (vereist opleidingsniveau en productiviteit) maar ook door de stabiliteit van hun loopbaan en het volgen van additioneel onderwijs. Een onstabiel verloop van de beroepscarrière, dat wil zeggen vaak van baan veranderen, blijkt niet bevorderlijk te zijn voor de productiviteit; het leidt tot een lager loon.

Het loon blijkt lager te zijn wanneer men nog bezig is met het volgen van een tweede fase-opleiding of post-doctorale beroepsopleiding. Dit tijdelijk verlies aan inkomen kan worden gezien als een investering die later wellicht haar rendement oplevert in de vorm van een hoger loon (het positief looneffect van een afgeronde tweede faseopleiding of post-doctorale beroepsopleiding is net niet significant). 


\section{Resumé}

De kwaliteit van het werk, zoals deze zich zo'n vijf jaar na het afstuderen heeft uitgekristalliseerd, hangt niet alleen samen met het volgen van additioneel onderwijs maar ook met de stabiliteit van de loopbaan. De kwaliteit van het latere werk is daarnaast afhankelijk van de kwaliteit van de baan waarin men de loopbaan is gestart. 


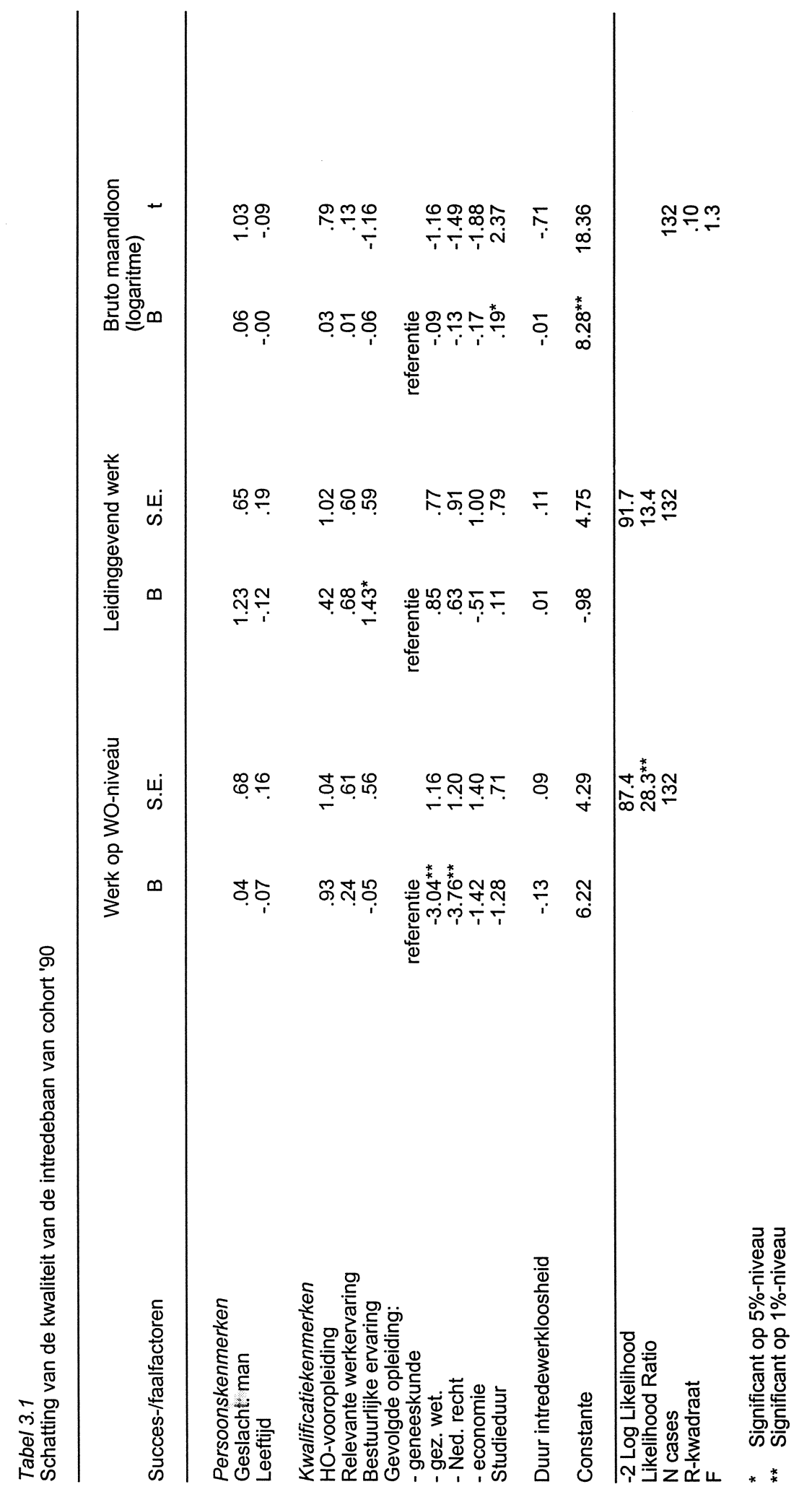




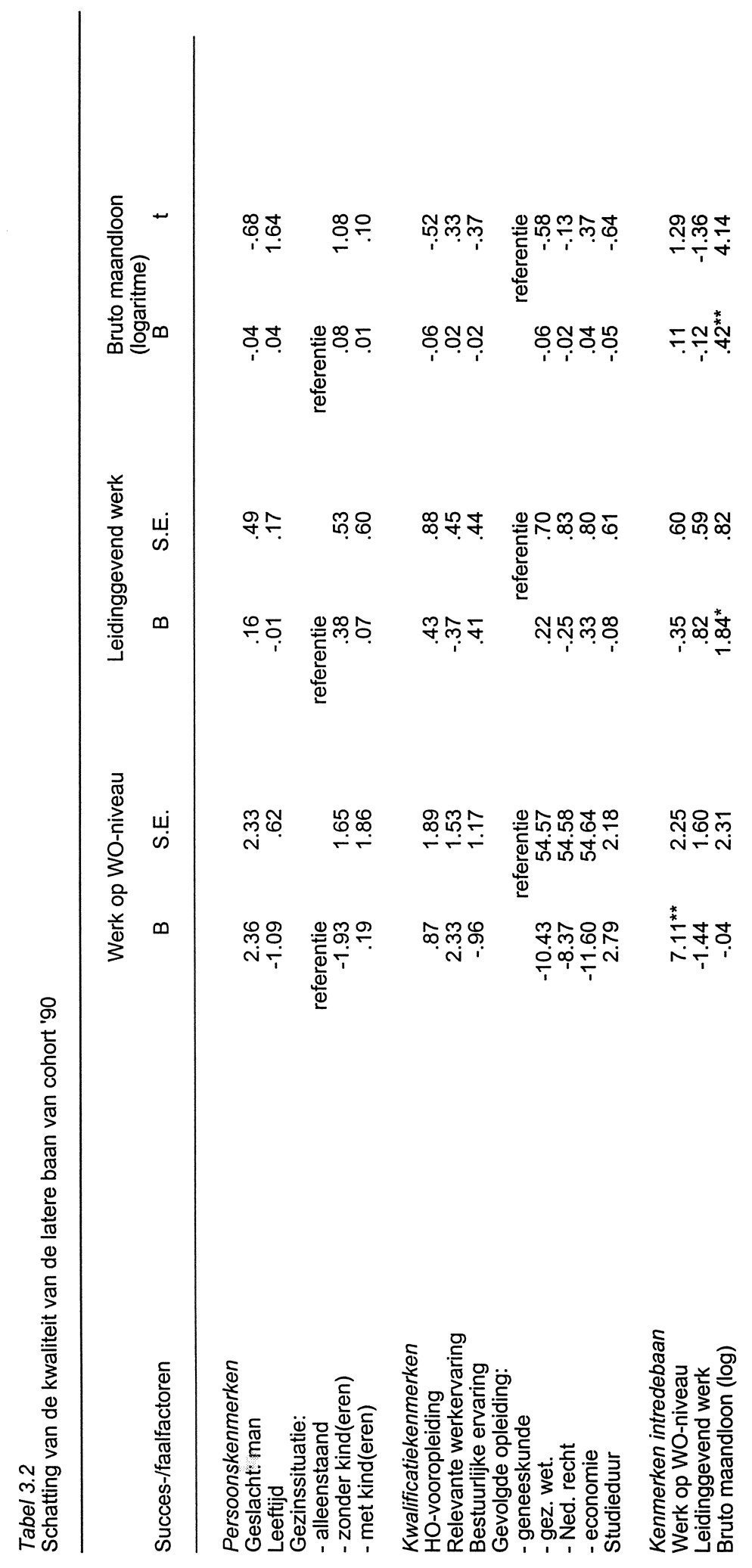




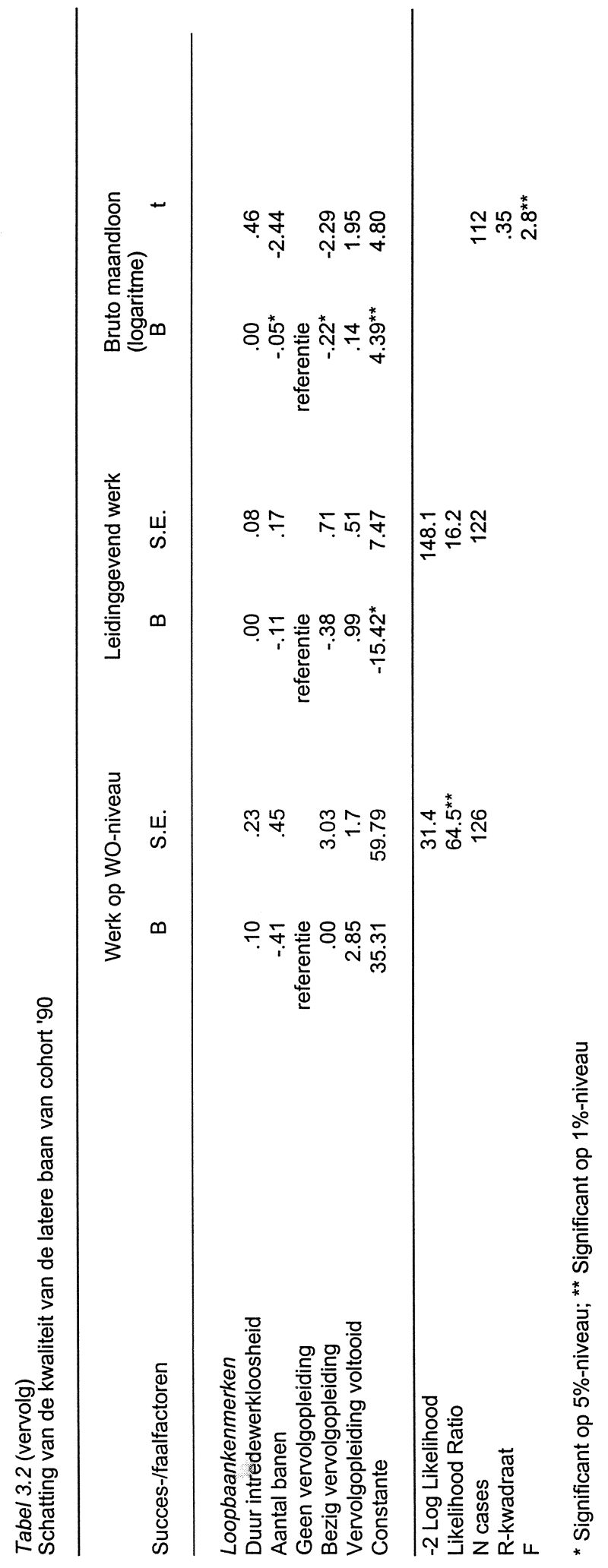




\section{Afstemming tussen opleiding en later werk}

\subsection{Inhoudelijke discrepanties en PGO}

Eenmalig is in een mutatiemeting 'oude stijl', namelijk de in 1993 uitgevoerde tweede mutatiemeting aan de betaald-werkende oudstudenten een lijst met een aantal aspecten voorgelegd die voor een goede beroepsuitoefening van belang kunnen zijn. De resultaten in dit hoofdstuk hebben betrekking op oudstudenten die op het moment van deze tweede mutatiemeting betaald werk verrichten en in de periode januari 1986 - juni 1988 zijn afgestudeerd. Op het moment van de tweede mutatiemeting varieert de lengte van de loopbaan na het afstuderen van circa vijf jaar bij degenen die in de eerste helft van 1988 zijn afgestudeerd tot zo'n zeven jaar bij afstudeercohort '86. Deze cohorten zijn in 1990 voor de eerste keer bevraagd met behulp van een retrospectieve basisvragenlijst.

De tabellen 4.1 en 4.2 geven een beeld van de wijze waarop de respons zich in de drie opeenvolgende metingen heeft ontwikkeld, onderscheiden naar achtereenvolgens het jaar waarin men is afgestudeerd (tabel 4.1) en de faculteit waarin men is afgestudeerd (tabel 4.2). Tabel 4.1 laat zien dat het grootste responsverlies is opgetreden tussen de eerste en de tweede meting. Zo is de respons bij de tweede meting ten opzichte van de eerste meting met $21 \%$-punt gedaald, tot $56 \%$ van de oorspronkelijke totale populatie. Hierbij dient te worden opgemerkt dat bij iedere mutatiemeting de oorspronkelijke populatie steeds in haar totaliteit is aangeschreven, dus inclusief degenen die bij een eerdere meting niet hadden gereageerd. De responsdaling lijkt eerder het gevolg te zijn van enquêtemoeheid of een verminderde binding met de UM (bij een deel van de oudstudenten) dan van een veroudering van het adressenbestand. Immers, het verschil in repons bij de retrospectieve basismeting tussen cohort '86 (de meest verouderde adressen) en cohort '88 (de minst verouderde adressen) bedraagt $2 \%$. Dit is beduidend kleiner dan het responsverlies tussen de eerste meting en de tweede meting (21\%). Verder komt in tabel 4.1 naar voren dat het responsverlies tussen de eerste en laatste meting bij cohort ' 88 met $27 \%$ het grootst is en bij cohort ' 86 met $22 \%$ het kleinst. Hierbij kan de gewijzigde samenstelling naar faculteit een rol spelen, aangezien de respons naar faculteit verschilt (tabel 4.2).

Overigens kunnen de oudstudenten op basis van hun enquêtegedrag in vier groepen worden ingedeeld:

$\begin{array}{lll}\text { - oudstudenten die aan geen enkele enquête hebben meegedaan } & 135 \quad 19 \%\end{array}$

- oudstudenten die alleen aan de basismeting hebben meegedaan $\quad 177 \quad 25 \%$

- oudstudenten die alleen aan de 2e meting hebben meegedaan $\quad 30 \quad 4 \%$

$\begin{array}{lll}\text { - oudstudenten die aan alle metingen hebben meegedaan } & 368 \quad 52 \%\end{array}$

Totaal

$710 \quad 100 \%$ 
Tabel 4.1

Respons retrospectieve basismeting 1990 en mutatiemetingen 1992 en 1993, afstudeercohorten '86-'88

\begin{tabular}{lllll}
\hline Cohort & N afgestudeerden & $\begin{array}{l}\text { Retrospectieve } \\
\text { basismeting }\end{array}$ & $\begin{array}{l}\text { Eerste } \\
\text { mutatiemeting }\end{array}$ & $\begin{array}{l}\text { Tweede } \\
\text { mutatiemeting }\end{array}$ \\
\hline 1986 & 228 & $173=76 \%$ & $130=57 \%$ & $122=54 \%$ \\
1987 & 297 & $228=77 \%$ & $161=54 \%$ & $\begin{array}{r}151=51 \% \\
95=51 \%\end{array}$ \\
$1988^{*}$ & 185 & $144=78 \%$ & $107=58 \%$ & $368=52 \%$ \\
Totaal & 710 & $545=77 \%$ & $398=56 \%$ & 368 \\
\hline
\end{tabular}

${ }^{\text {*} E e r s t e ~ h e l f t ~ v a n ~ k a l e n d e r j a a r ~} 1988$

Tabel 4.2 geeft een beeld van de wijze waarop de respons zich in de drie opeenvolgende metingen heeft ontwikkeld, onderscheiden naar de faculteit waarin men is afgestudeerd. In deze tabel komt naar voren dat de respons onder juristen afwijkt van het gemiddelde beeld. Bij iedere meting is de respons onder juristen beduidend lager dan onder oudstudenten van de andere faculteiten. Daarbij komt dat de mate van responsverlies, gerekend tussen de derde meting en de eerste meting onder juristen groter is dan onder de andere oudstudenten. Het responsverlies onder juristen bedraagt $28 \%$-punt, tegen $26 \%$-punt onder basisartsen en $21 \%$-punt onder gezondheidswetenschappers. Het is dan ook niet verwonderlijk dat het procentuele aandeel van oudstudenten die aan geen enkele meting hebben meegedaan onder juristen met $26 \%$ het hoogst is, tegen slechts $14 \%$ bij basisartsen en $15 \%$ bij gezondheidswetenschappers.

Tabel 4.2

Respons retrospectieve basismeting 1990 en mutatiemetingen 1992 en 1993 naar faculteit, cohorten ' $86-' 88$

\begin{tabular}{lllll}
\hline Faculteit & N afgestudeerden & $\begin{array}{l}\text { Retrospectieve } \\
\text { basismeting }\end{array}$ & $\begin{array}{l}\text { Eerste } \\
\text { mutatiemeting }\end{array}$ & $\begin{array}{l}\text { Tweede } \\
\text { mutatiemeting }\end{array}$ \\
\hline FdG & 205 & $172=84 \%$ & $123=60 \%$ & $118=58 \%$ \\
FdGW & 239 & $196=82 \%$ & $152=64 \%$ & $146=61 \%$ \\
FdR & 266 & $177=67 \%$ & $123=46 \%$ & $104=39 \%$ \\
Totaal & 710 & $545=77 \%$ & $398=56 \%$ & $368=52 \%$ \\
\hline
\end{tabular}

Aangezien er ten tijde van de retrospectieve basismeting nog geen economen waren afgestudeerd, zijn de onderzoeksresultaten in dit hoofdstuk beperkt tot afgestudeerden van de FdG, FdGW en FdR. Wel zijn economen voor het eerst meegenomen in de tweede mutatiemeting (voor de desbetreffende economen was dit de eerste mutatiemeting). Vandaar dat in de bijlage wel een tabel is opgenomen met betrekking tot afgestudeerde economen. 
Eerder is naar voren gekomen dat het responsverlies tussen de eerste en laatste meting het kleinst is bij cohort ' 86 en het grootst bij cohort ' 88 . Hier zal niet vreemd aan zijn dat het procentuele aandeel van juristen is gestegen van $27 \%$ bij cohort ' 86 , via $41 \%$ bij cohort ' 87 tot $45 \%$ bij cohort ' 88 .

In dit hoofdstuk wordt nagegaan welke specifieke kwalificaties voor oudstudenten van belang zijn bij hun latere beroepsuitoefening en in hoeverre deze kwalificaties voldoende aan bod zijn gekomen tijdens de opleiding. Centraal staan eventuele inhoudelijke discrepanties tussen het genoten onderwijs en het uitgeoefende werk. Hiervan is sprake wanneer de kwalificaties die in het onderwijs worden bijgebracht niet passen bij de kwalificaties die worden vereist vanuit het werkveld. Het is daarbij van belang om op te merken dat hier uitsluitend het oordeel van de oudstudenten aan bod komt. Dit hoeft uiteraard niet overeen te stemmen met het oordeel vanuit het werkveld.

Voor het achterhalen van eventuele inhoudelijke discrepanties is aan de betaaldwerkende oudstudenten een lijst van 18 kwalificatie-items voorgelegd die voor een goede uitoefening van hun latere functie mogelijk van belang zijn. Deze items verwijzen naar eisen ten aanzien van kennis, vaardigheden en persoonseigenschappen, die onder meer zijn ontleend aan literatuur over functie-analyse (zie: Algera ${ }^{7}$ ). De kwalificatie-items zijn zo geformuleerd dat zij voor mensen uit verscheidene werkvelden toepasbaar zijn. Deze items lopen uiteen van vakkennis tot en met sociale vaardigheden zoals leidinggevende en contactuele vaardigheden, en persoonseigenschappen zoals aanpassingsvermogen en accuratesse.

Bij ieder van deze items konden de oudstudenten eerst aangegeven in hoeverre zij de betreffende kwalificatie van belang achten voor een goede vervulling van hun latere werkzaamheden, vervolgens of in de door hen gevolgde opleiding aan de UM meer, evenveel of minder aandacht aan de genoemde kwalificatie moet worden besteed (vergeleken met de hoeveelheid aandacht die het desbetreffende kwalificatie-item tijdens hun opleiding aan de UM heeft gekregen) en tenslotte of zij van mening zijn dat zij deze kwalificaties al dan niet beter beheersen dan traditioneel opgeleide academici dankzij het probleemgestuurd onderwijs (PGO). De resultaten staan vermeld in tabel 4.3 en per faculteit in bijlage 2 .

\section{Belang van kennis en vaardigheden}

De oudstudenten konden het belang dat zij aan een bepaald kwalificatie-item toekennen op een vierpuntsschaal aangeven. Deze schaal bevat de categorieën: onbelangrijk, vrij onbelangrijk, tamelijk belangrijk en zeer belangrijk. In tabel 4.3

7. Algera, J.A. (redactie, 1991), Analyse van arbeid vanuit verschillende perspectieven, Swets \& Zeitlinger, Amsterdam/Lisse. 
staat in de kolom 'Belangrijk in praktijk' voor ieder aspect het percentage betaaldwerkende oudstudenten dat het betreffende aspect tamelijk of zeer belangrijk vindt voor een goede uitoefening van hun latere functie. Uit de tabel blijkt dat alle genoemde kwalificatie-aspecten, behoudens beheersing van vreemde talen, door de meerderheid van de oudstudenten belangrijk worden geacht voor het vervullen van de latere functie. Bij 13 van de 18 aspecten vindt zelfs tenminste driekwart van de betaald-werkende oudstudenten dat dit aspect belangrijk is voor een goede uitoefening van de functie. De genoemde aspecten zijn blijkbaar in hoge mate relevant voor het typeren van de kwalificaties die oudstudenten bij hun latere beroepsuitoefening nodig hebben.

De juiste persoonseigenschappen worden door oudstudenten het vaakst van belang geacht voor het later goed kunnen functioneren in het werk. Het gaat hierbij om kwalificatie-aspecten waarbij gemiddeld $95 \%$ van de betaald-werkende oudstudenten heeft aangegeven dat deze tamelijk of zeer belangrijk zijn voor de functievervulling. Vaardigheden en kennis-items worden door de bank genomen iets minder belangrijk gevonden.

\section{Gewenste aandacht voor kennis en vaardigheden}

Door het volgen van opleidingen moeten mensen dié kwalificaties leren die nodig zijn om meer of minder gespecialiseerde arbeidsprestaties te kunnen leveren. Vanuit de arbeidsmarkt bezien, moet een opleiding derhalve in de juiste mate aandacht besteden aan kwalificaties die van belang zijn voor een goede beroepsuitoefening. Daarom is nagegaan of de genoemde beroepsrelevante kwalificatie-aspecten tijdens de opleiding wel voldoende aan bod zijn gekomen volgens de oudstudenten (het is overigens nog maar de vraag of juist tijdens de opleiding meer aandacht moet en kan worden geschonken aan bijvoorbeeld de juiste persoonseigenschappen die in een werkkring zo belangrijk blijken te zijn).

De betaald-werkende oudstudenten konden in de vragenlijst per aspect aangeven of hieraan tijdens de door hen gevolgde studie meer, evenveel of minder aandacht moet worden besteed. Hierbij moet worden opgemerkt dat oudstudenten zich niet altijd realiseren dat meer aandacht voor het ene aspect, bij een gelijkblijvende studieduur, minder aandacht voor een ander aspect betekent. De derde kolom van tabel 4.3 toont per kwalificatie-item hoeveel procent van de betaald-werkende oudstudenten van mening is dat aan het desbetreffende item tijdens de opleiding aan de UM meer aandacht zou moeten worden besteed. Naar voren komt dat met name aan vaardigheden nog meer aandacht zou moeten worden besteed dan nu reeds het geval is tijdens de opleiding. 
Tabel 4.3

Afstemming tussen onderwijs en latere beroepspraktijk en de rol van PGO, mutatiemeting 1993: cohorten '86-'88

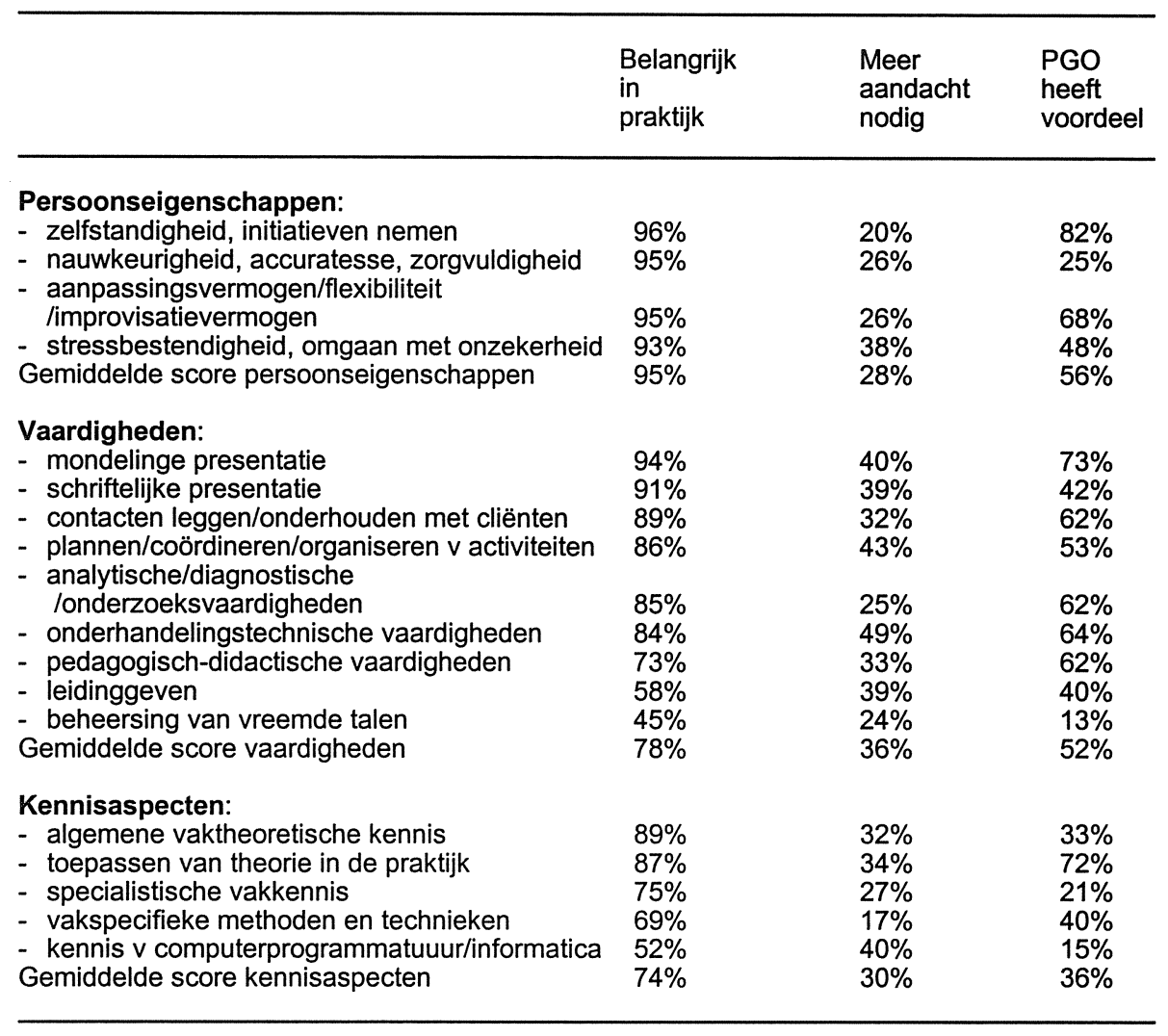

Wanneer de resultaten over het belang van de kwalificaties in de beroepspraktijk worden vergeleken met de resultaten over de benodigde aandacht hiervoor, valt op dat de kwalificatie-aspecten die het vaakst van belang blijken te zijn bij het uitoefenen van de functie niet altijd de aspecten zijn waaraan volgens de oudstudenten meer aandacht zou moeten worden besteed tijdens de opleiding. Terwijl bijvoorbeeld $96 \%$ van de betaald-werkende oudstudenten van mening is dat zelfstandigheid en initiatief van belang zijn om de latere functie goed te kunnen uitoefenen, vindt 'slechts' $20 \%$ dat er tijdens de opleiding aan de UM meer aandacht moet zijn voor dit aspect. Dit laat onverlet dat er ook houdingsaspecten zijn waarvoor wel relatief vaak meer aandacht wordt gevraagd, bijvoorbeeld voor stressbestendigheid en omgaan met onzekerheid.

Uit tabel 4.3 blijkt verder dat tenminste $40 \%$ van de oudstudenten meer aandacht nodig acht voor mondelinge presentatie, plannen/coördineren/organiseren van activiteiten, onderhandelingstechnische vaardigheden en kennis van computerprogrammatuuur en informatica. Dit betekent dat er tijdens de opleiding meer ruimte 
zou moeten zijn voor training op deze terreinen, hetzij in aanvullende lessen (in het geval van kennis van computerprogrammatuuur en informatica), hetzij door een andere vormgeving van het bestaande onderwijs (in het geval van mondelinge presentatie, plannen/coördineren/organiseren van activiteiten en onderhandelingstechnische vaardigheden). Ook stages lenen zich goed voor het aanleren van dergelijke vaardigheden. De faculteiten zouden ook nascholingscursussen op deze terreinen kunnen aanbieden.

\section{PGO-voordeel}

Tenslotte is aan de oudstudenten gevraagd of zij de verschillende kwalificaties beter beheersen dan traditioneel opgeleide vakgenoten omdat zij PGO hebben genoten. Zij konden deze vraag met ja of nee beantwoorden. In de vierde kolom van tabel 4.3 staat per kwalificatie-item vermeld hoeveel procent van de betaald-werkende oudstudenten van mening is dat zij de desbetreffende kwalificatie beter beheersen dan traditioneel opgeleide vakgenoten omdat zij PGO hebben gevolgd. Bij de helft van de 18 kwalificatie-aspecten vindt de meerderheid van de oudstudenten dat PGO hen beter op de latere beroepspraktijk heeft voorbereid dan traditioneel onderwijs. Naar de mening van de oudstudenten is PGO het sterkst in het stimuleren van de volgende persoonseigenschappen: zelfstandigheid/initiatieven nemen en aanpassingsvermogen/flexibiliteit/improvisatievermogen. Bovendien wordt een voordeel van PGO ervaren bij het verwerven van vaardigheden als mondelinge presentatie, onderhandelingstechnische vaardigheden, contacten leggen/onderhouden met cliënten, analytische/diagnostische/onderzoeksvaardigheden, pedagogisch-didactische vaardigheden, plannen/coördineren/organiseren van activiteiten en de praktische toepassing van kennis.

\section{Confrontatie van beroepsrelevantie en gewenste aandacht tijdens de opleiding}

In tabel 4.3 staat in kolom 2 en 3 achtereenvolgens vermeld hoeveel procent van de betaald-werkende oudstudenten de betreffende kwalificatie van belang achten voor een goede vervulling van hun latere werkzaamheden en hoeveel procent van mening is dat deze kwalificatie meer aandacht behoeft tijdens de opleiding aan de UM. Het is de vraag of het hierbij steeds om dezelfde oudstudenten gaat. Teneinde deze vraag te kunnen beantwoorden, vindt in tabel 4.4 een confrontatie plaats van het belang dat oudstudenten toekennen aan kwalificaties met de aandacht die deze kwalificaties volgens hen behoeven in de opleiding.

Op basis van het belang voor de latere beroepsuitoefening en de gewenste aandacht tijdens de opleiding zijn per kwalificatie-item de volgende drie antwoordcategorieën opgesteld, die een indicatie vormen van de oplopende mate waarin er sprake is van een discrepantieprobleem:

1 kwalificatie is belangrijk voor de beroepsuitoefening en heeft voldoende aandacht 
gekregen;

2 kwalificatie is onbelangrijk voor de beroepsuitoefening en heeft al dan niet voldoende aandacht gekregen;

3 kwalificatie is belangrijk voor de beroepsuitoefening en heeft onvoldoende aandacht gekregen.

In de meest optimale situatie scoort antwoordcategorie ' 1 ' $100 \%$, dit wil zeggen dat alle respondenten vinden dat het desbetreffende kwalificatie-item niet alleen belangrijk is voor de beroepsuitoefening, maar ook tijdens de opleiding voldoende aandacht heeft gekregen. In de meest ongunstige situatie scoort antwoordcategorie '3' $100 \%$, dit wil zeggen dat alle respondenten vinden dat het desbetreffende kwalificatie-item belangrijk is voor de beroepsuitoefening en tijdens de opleiding onvoldoende aan bod is gekomen.

Tabel 4.4

Confrontatie van onderwijs met latere beroepspraktijk, mutatiemeting 1993: cohorten '86-'88

\begin{tabular}{|c|c|c|c|}
\hline & $\begin{array}{l}\text { Belangrijk, } \\
\text { voldoende } \\
\text { aandacht } \\
\text { gekregen }\end{array}$ & Onbelangrijk & $\begin{array}{l}\text { Belangrijk, } \\
\text { onvoldoende } \\
\text { aandacht } \\
\text { gekregen }\end{array}$ \\
\hline $\begin{array}{l}\text { Persoonseigenschappen: } \\
\text { - zelfstandigheid, initiatieven nemen } \\
\text { - nauwkeurigh, accuratesse, zorgvuldigh } \\
\text { - flexibiliteit/improvisatievermogen } \\
\text { - stressbestendigh, omgaan met onzekerh } \\
\text { Gemiddelde score persoonseigensch }\end{array}$ & $\begin{array}{l}76 \% \\
69 \% \\
69 \% \\
56 \% \\
68 \%\end{array}$ & $\begin{array}{l}5 \% \\
5 \% \\
6 \% \\
7 \% \\
6 \%\end{array}$ & $\begin{array}{l}19 \% \\
26 \% \\
26 \% \\
37 \% \\
27 \%\end{array}$ \\
\hline $\begin{array}{l}\text { Kennisaspecten: } \\
\text { - algemene vaktheoretische kennis } \\
\text { - specialistische vakkennis } \\
\text { - vakspecifieke methoden en technieken } \\
\text { - toepassen van theorie in de praktijk } \\
\text { - kennis v computerprogram./informatica } \\
\text { Gemiddelde score kennisaspecten }\end{array}$ & $\begin{array}{l}59 \% \\
51 \% \\
53 \% \\
55 \% \\
24 \% \\
48 \%\end{array}$ & $\begin{array}{l}11 \% \\
24 \% \\
32 \% \\
12 \% \\
48 \% \\
26 \%\end{array}$ & $\begin{array}{l}31 \% \\
25 \% \\
15 \% \\
32 \% \\
29 \% \\
26 \%\end{array}$ \\
\hline $\begin{array}{l}\text { Vaardigheden: } \\
\text { - schriftelijke presentatie } \\
\text { - mondelinge presentatie } \\
\text { - beheersing van vreemde talen } \\
\text { - pedagogisch-didactische vaardigheden } \\
\text { - contacten met cliënten } \\
\text { - onderhandelings-technische vaardigh. } \\
\text { - plannen/coördineren activiteiten } \\
\text { - leidinggeven } \\
\text { - analytische/diagnostisch vaardigheden } \\
\text { Gemiddelde score vaardigheden }\end{array}$ & $\begin{array}{l}55 \% \\
55 \% \\
25 \% \\
43 \% \\
59 \% \\
36 \% \\
44 \% \\
28 \% \\
60 \% \\
45 \%\end{array}$ & $\begin{array}{r}9 \% \\
6 \% \\
55 \% \\
27 \% \\
11 \% \\
17 \% \\
15 \% \\
42 \% \\
15 \% \\
22 \%\end{array}$ & $\begin{array}{l}36 \% \\
39 \% \\
20 \% \\
30 \% \\
31 \% \\
47 \% \\
42 \% \\
30 \% \\
25 \% \\
33 \%\end{array}$ \\
\hline
\end{tabular}

Uit tabel 4.4 komt naar voren dat discrepanties zich door de bank genomen sterker manifesteren bij vaardigheden en in mindere mate kennisaspecten dan bij persoonseigenschappen. De discrepanties zijn het grootst (antwoordcategorie ' 3 ' scoort $>33 \%$ ) met betrekking tot het attitude-item stressbestendigheid, omgaan met 
onzekerheid en bij de vaardigheidsaspecten onderhandelings-technische vaardigheden, plannen/coördineren van activiteiten, mondeling presenteren en schriftelijk presenteren.

Minder ernstige problemen (antwoordcategorie '2' scoort > 33\%) doen zich voor met betrekking tot de kwalificaties: beheersing van vreemde talen, kennis van computerprogrammatuur/informatica en leidinggeven. Discrepantieproblemen zijn het kleinst (antwoordcategorie ' 1 ' scoort > 66\%) bij de drie attitude-items: zelfstandigheid/initiatieven nemen, nauwkeurigheid/accuratesse/zorgvuldigheid en aanpassingsvermogen/flexibiliteit/improvisatievermogen.

\subsection{Analyse van het belang van kwalificaties}

Er is nagegaan welke (loop)baankenmerken van invloed zijn op het belang dat de 18 kwalificatie-items hebben voor de latere beroepsuitoefening. Teneinde de hoeveelheid informatie te beperken, zijn eerst de 18 kwalificatie-items teruggebracht tot vier orthogonale factoren door middel van principale factoren analyse. De volgende vier factoren (eigenvalue $>1.0$ ), die tesamen $61 \%$ van de variantie in het factor analytisch model verklaren, kunnen worden onderscheiden. In de eerste plaats de factor 'persoonseigenschappen' waarop, na varimax rotatie, de volgende vijf kwalificatieitems een factorlading hebben >.5: aanpassingsvermogen/ flexibiliteit/improvisatievermogen, stressbestendigheid/omgaan met onzekerheid, zelfstandigheid/initiatieven nemen, nauwkeurigheid/accuratesse/zorgvuldigheid en mondeling presenteren. Vier kwalificatie-items, namelijk specialistische vakkennis, vakspecifieke methoden en technieken, algemene vaktheoretische kennis en toepassen van theorie in de praktijk vormen samen een tweede factor 'vakkennis'. Als derde factor kwamen 'managementkwaliteiten' naar voren, gevormd door de kwalificatie-items leidinggeven, plannen/coördineren/organiseren van activiteiten en onderhandelings-technische vaardigheden. Het kwalificatie-item 'schriftelijk presenteren' is als vierde factor naar voren is gekomen. De factoren zijn zo geoperationaliseerd dat naarmate de score van een respondent op een factor (de factorscore) hoger is, de respondent de desbetreffende factor belangrijker vindt voor een goede uitoefening van zijn of haar beroep.

Met behulp van lineaire regressie-analyse is vervolgens nagegaan welke kenmerken een verklaring kunnen bieden voor het belang dat de vier bovengenoemde kwalificatieclusters gaandeweg de loopbaan hebben voor een goede beroepsuitoefening. De resultaten van deze schattingen worden in tabel 4.5 weergegeven. $\mathrm{Bij}$ een van de verklarende variabelen is een referentiecategorie opgenomen. De resultaten van de overige categorieën zijn dan gerelateerd aan deze referentiecategorie.

Als verklarende variabelen voor de latere beroepsrelevantie van de vier kwalifica- 
tieclusters zijn in iedere schatting steeds het geslacht, de aan de UM gevolgde opleidingsrichting, het aantal maanden dat men reeds is afgestudeerd en vier kenmerken van de latere functie opgenomen. De vier in de analyses opgenomen baankenmerken zijn achtereenvolgens het niveau en de richting van de opleiding die voor de latere functie is vereist, het al dan niet uitoefenen van een leidinggevende functie, de grootte van de werkorganisatie en het al dan niet werken in de profit sector.

Voor deze verklarende variabelen zijn dummies geconstrueerd, behoudens voor het aantal maanden dat men reeds is afgestudeerd (duur loopbaan) en de grootte van de werkorganisatie (grotere organisatie). De dummy-variabelen hebben achtereenvolgens betrekking op de aan de UM gevolgde opleidingsrichting: geneeskunde, $B B$ (beleid en beheer van gezondheidszorgvoorzieningen), GVO (gezondheidsvoorlichting), $V W$ (verplegingswetenschap) en $N e d$. recht ${ }^{8}$, een functie waarvoor een academische opleiding is vereist (werk op WO-niveau), een functie waarvoor de aan de UM gevolgde opleiding is vereist (werk in eigen richting), het uitoefenen van een leidinggevende functie (leidinggevend werk) en het werken in de profit sector (profit sector). In iedere schatting fungeerde geneeskunde als referentie voor de gevolgde opleidingsrichting. Voor de precieze omschrijving van de dummy-codes wordt verwezen naar bijlage 3 .

\section{Belang van persoonseigenschappen}

De schattingsresultaten van de regressievergelijking met betrekking tot het belang van persoonseigenschappen voor een goede beroepsuitoefening staan vermeld in de tweede kolom van tabel 4.5. De resultaten laten zien dat vrouwen persoonseigenschappen belangrijker vinden voor een goede uitoefening van de latere functie dan mannen.

\section{Belang van vakkennis}

Oudstudenten met werk dat aansluit bij hun opleidingsrichting vinden vakkennis belangrijker voor een goede vervulling van hun latere functie dan oudstudenten die buiten hun 'eigen' opleidingssector werkzaam zijn. Verder komt naar voren dat oudstudenten geneeskunde vakkennis belangrijker vinden dan oudstudenten BB en Nederlands recht.

8. Onder de in 1986-1988 afgestudeerde respondenten van de mutatiemeting 1993/1994 bevonden zich nog geen afgestudeerden economie of bewegingswetenschap. Aangezien zich onder deze respondenten slechts 2 oud-studenten biologische gezondheidkunde, 2 oudstudenten theorie der gezondheidswetenschappen en 1 oudstudent geestelijke gezondheidkunde bevonden, heeft het opnemen van dummies voor deze afstudeervarianten binnen gezondheidswetenschappen weinig zin. Vandaar dat deze 5 oudstudenten niet in deze analyses zijn opgenomen. 


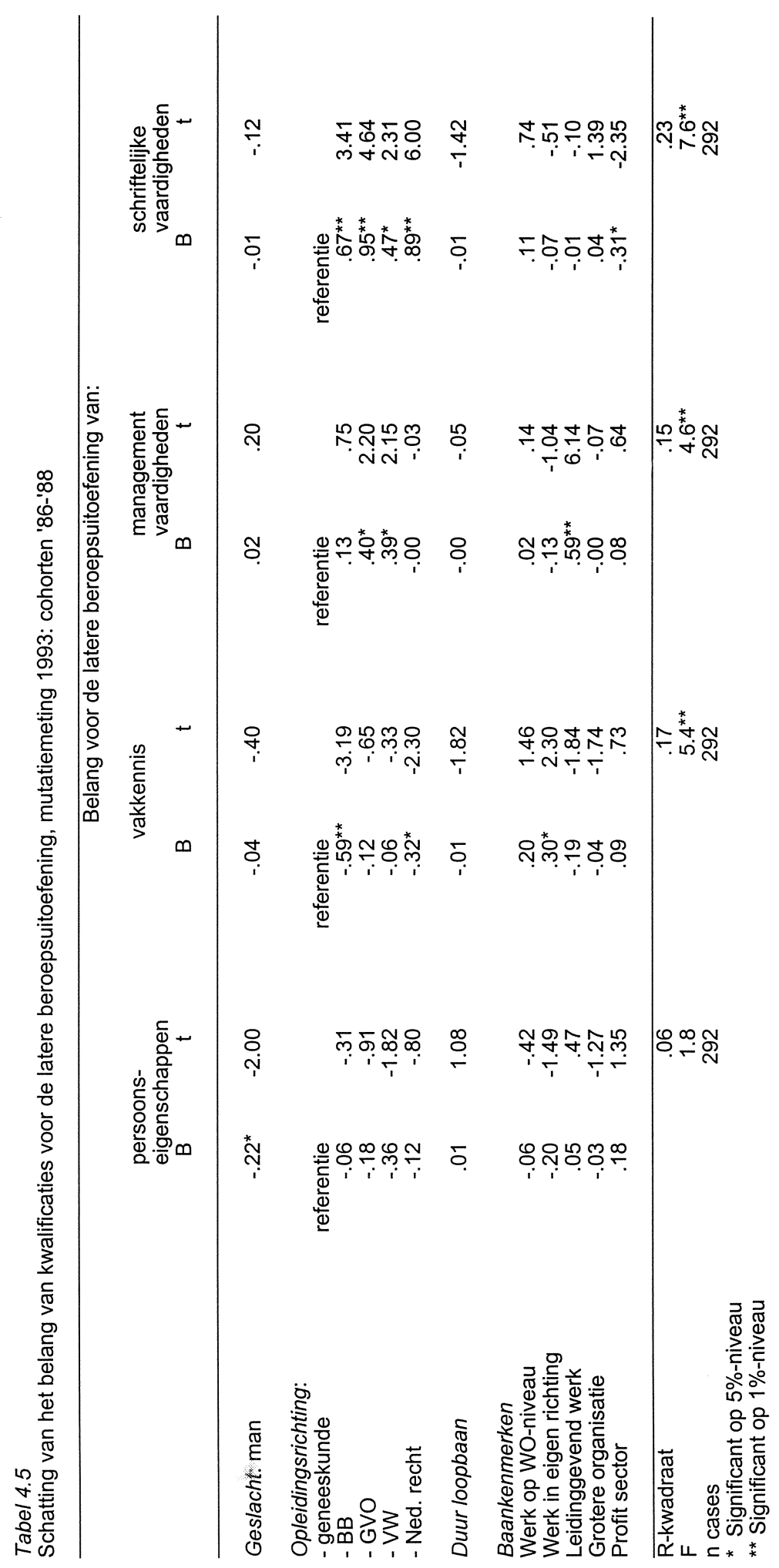


Belang van managementvaardigheden

Zoals mag worden verwacht, zijn managementvaardigheden belangrijker voor degenen die een leidinggevende functie uitoefenen dan voor degenen die nietleidinggevend werk verrichten. De resultaten laten verder zien dat oudstudenten GVO en VW een groter belang toekennen aan managementvaardigheden dan basisartsen.

\section{Belang van schriftelijke vaardigheden}

Voor oudstudenten geneeskunde blijken schriftelijke vaardigheden minder belangrijk te zijn dan voor andere afgestudeerden van de UM. In tabel 4.5 komt verder naar voren dat men in de non-profit sector meer waarde hecht aan schriftelijke vaardigheden dan in de profit sector.

\subsection{Analyse van de gewenste aandacht voor kwalificaties}

Nadat is beschreven welke (loop)baankenmerken van invloed zijn op het belang dat de onderscheiden kwalificaties gaandeweg de loopbaan hebben voor de beroepsuitoefening, wordt hieronder nagegaan welke kenmerken van invloed zijn op de wijze waarop oudstudenten achteraf de opleiding beoordelen, dit wil zeggen in hoeverre zij vinden dat de 18 kwalificatie-items voldoende aan bod zijn gekomen. Teneinde de hoeveelheid informatie te beperken, zijn de 18 kwalificatie-items middels principale factoren analyse eerst teruggebracht tot zes orthogonale factoren (eigenvalue $>1.0$ ) die tesamen $60 \%$ van de variantie in het factor analytisch model voor hun rekening nemen. In de eerste plaats de factor 'managementvaardigheden' waarop na varimax rotatie drie kwalificatie-items een factorlading hebben $>.5$, namelijk leidinggeven, plannen/coördineren/organiseren van activiteiten en onderhandelingstechnische vaardigheden. De drie kwalificatie-items aanpassingsvermogen/flexibiliteit/improvisatievermogen, stressbestendigheid/omgaan met onzekerheid en zelfstandigheid/initiatieven nemen, vormen samen de factor 'persoonseigenschappen'. Het kwalificatie-item 'vakspecifieke methoden en technieken' vormt de derde factor 'M\&T' die in de analyse naar voren is gekomen. Een vierde factor wordt gevormd door het kwalificatie-item 'schriftelijk presenteren'. Het kwalificatie-item 'kennis van computerprogrammatuuur en informatica' vormt de vijfde factor 'computervaardigheden'. Tenslotte vormt het kwalificatie-item 'beheersing van vreemde talen' de zesde factor. De factoren zijn zo geoperationaliseerd dat naarmate de score van een respondent op een factor (de factorscore) hoger is, de respondent van mening is dat aan de desbetreffende factor meer aandacht moet worden besteed tijdens de opleiding.

Met behulp van lineaire regressie-analyse is vervolgens nagegaan welke kenmerken een verklaring kunnen bieden voor de aandacht die volgens de oudstudenten aan 
de zes bovengenoemde factoren zou moeten worden besteed. De resultaten van deze schattingen worden in tabel 4.6 weergegeven. Bij een van de verklarende variabelen is een referentiecategorie opgenomen. De resultaten van de overige categorieën zijn dan gerelateerd aan deze referentiecategorie.

Aangezien de gewenste aandacht resulteert uit de confrontatie van vereiste kwalificaties (die naar soort werkorganisatie kunnen variëren) en beschikbare kwalificaties, zijn als verklarende variabelen voor de scores van de respondenten op de zes factoren in iedere schatting steeds drie soorten kenmerken opgenomen, namelijk een zestal kwalificaties waarover oudstudenten op het moment van de enquête beschikken, een zestal kwalificaties die van hen worden gevraagd en twee kenmerken van de werkomgeving.

Bij de zes kwalificaties waarover oudstudenten beschikken, gaat het achtereenvolgens om de genoten vooropleiding (HO-vooropleiding), de eventuele werk- en bestuurlijke ervaring die men vóór of tijdens de studie aan de UM heeft opgedaan (vroegere werkervaring en bestuurlijke ervaring), de opleidingsrichting waarin men aan de UM is afgestudeerd (geneeskunde, BB, GVO, VW of Ned. recht), de eventuele tweede fase opleiding of postdoctorale opleiding die men na het afstuderen heeft voltooid (vervolgonderwijs voltooid) en de lengte van de loopbaan na afstuderen (duur loopbaan). De zes vereiste kwalificaties betreffen achtereenvolgens het niveau van de opleiding die voor de functie is vereist (werk op WO-niveau), de richting van de vereiste opleiding (werk in eigen richting) en het belang dat de factoren persoonseigenschappen, vakkennis, managementvaardigheden en schriftelijke vaardigheden voor een goede uitoefening van het latere beroep hebben. Als organisatiekenmerken zijn de grootte van de werkorganisatie (grotere organisatie) en het al dan niet werken in de profit sector (profit sector) in de analyses opgenomen.

Voor deze verklarende variabelen zijn dummies geconstrueerd, behoudens voor het aantal maanden dat men reeds is afgestudeerd (duur loopbaan), de factorscores van persoonseigenschappen, vakkennis, managementvaardigheden en schriftelijke vaardigheden, alsmede de grootte van de werkorganisatie (grotere organisatie). In iedere schatting fungeerde geneeskunde als referentie voor de gevolgde opleidingsrichting. Voor de preciese omschrijving van de verklarende variabelen wordt verwezen naar bijlage 3 .

\section{Gewenste aandacht voor managementvaardigheden}

Tabel 4.6 laat zien dat oudstudenten BB, vergeleken met oudstudenten geneeskunde, wensen dat tijdens de opleiding meer aandacht aan managementvaardigheden wordt besteed dan thans het geval is. Dit is niet verwonderlijk aangezien de opleidingsrichting BB opleidt voor algemene beleids- en beheersfuncties binnen de 
gezondheidszorg en geneeskunde voor specialistische functies binnen de gezondheidszorg. Verder komt naar voren dat naarmate men langer geleden is afgestudeerd en bijgevolg verder met de beroepsloopbaan is gevorderd, men van mening is dat managementvaardigheden in de opleiding meer aandacht zouden moeten krijgen. Hetzelfde geldt naarmate persoonseigenschappen en managementvaardigheden belangrijker zijn voor een goede functie-uitoefening. Daarentegen zijn oudstudenten met functies die aansluiten bij de specifieke opleidingsrichting die men heeft gevolgd van mening dat aan managementvaardigheden best wat minder aandacht kan worden besteed.

\section{Gewenste aandacht voor attitudevorming}

Oudstudenten die werken in kleinere organisaties en oudstudenten die functies uitoefenen waarvoor persoonseigenschappen belangrijk zijn, vinden dat in de opleiding meer aandacht zou moeten worden besteed aan kwalificaties als aanpassingsvermogen/flexibiliteit/improvisatievermogen, stressbestendigheid/omgaan met onzekerheid en zelfstandigheid/initiatieven nemen.

\section{Gewenste aandacht voor vakspecifieke methoden en technieken}

Vergeleken met oudstudenten geneeskunde vinden oudstudenten BB dat vakspecifieke methoden en technieken tijdens de opleiding best wat meer aandacht zouden mogen krijgen dan thans het geval is. Hetzelfde geldt voor oudstudenten die functies uitoefenen waarbij het met name gaat om vakkennis.

\section{Gewenste aandacht voor schriftelijke vaardigheden}

In tabel 4.6 komt naar voren dat juristen, tenminste vergeleken met oudstudenten geneeskunde, vinden dat schriftelijk presenteren tijdens de opleiding best wat minder aandacht zou mogen krijgen dan thans het geval is. Verder blijkt dat oudstudenten met functies waarin persoonseigenschappen en schriftelijke vaardigheden belangrijk zijn, vinden dat aan schriftelijk presenteren best wat meer aandacht zou mogen worden besteed. De aandacht die men aan schriftelijke vaardigheden zou willen besteden, neemt af naarmate men over meer werkervaring beschikt.

\section{Gewenste aandacht voor computervaardigheden}

Vergeleken met oudstudenten van andere opleidingen zouden oudstudenten geneeskunde graag zien dat tijdens de opleiding meer aandacht wordt besteed aan kennis van computerprogrammatuuur en informatica dan thans het geval is. Hetzelfde geldt voor oudstudenten met functies waarbij managementvaardigheden belangrijk zijn voor een goede beroepsuitoefening. 


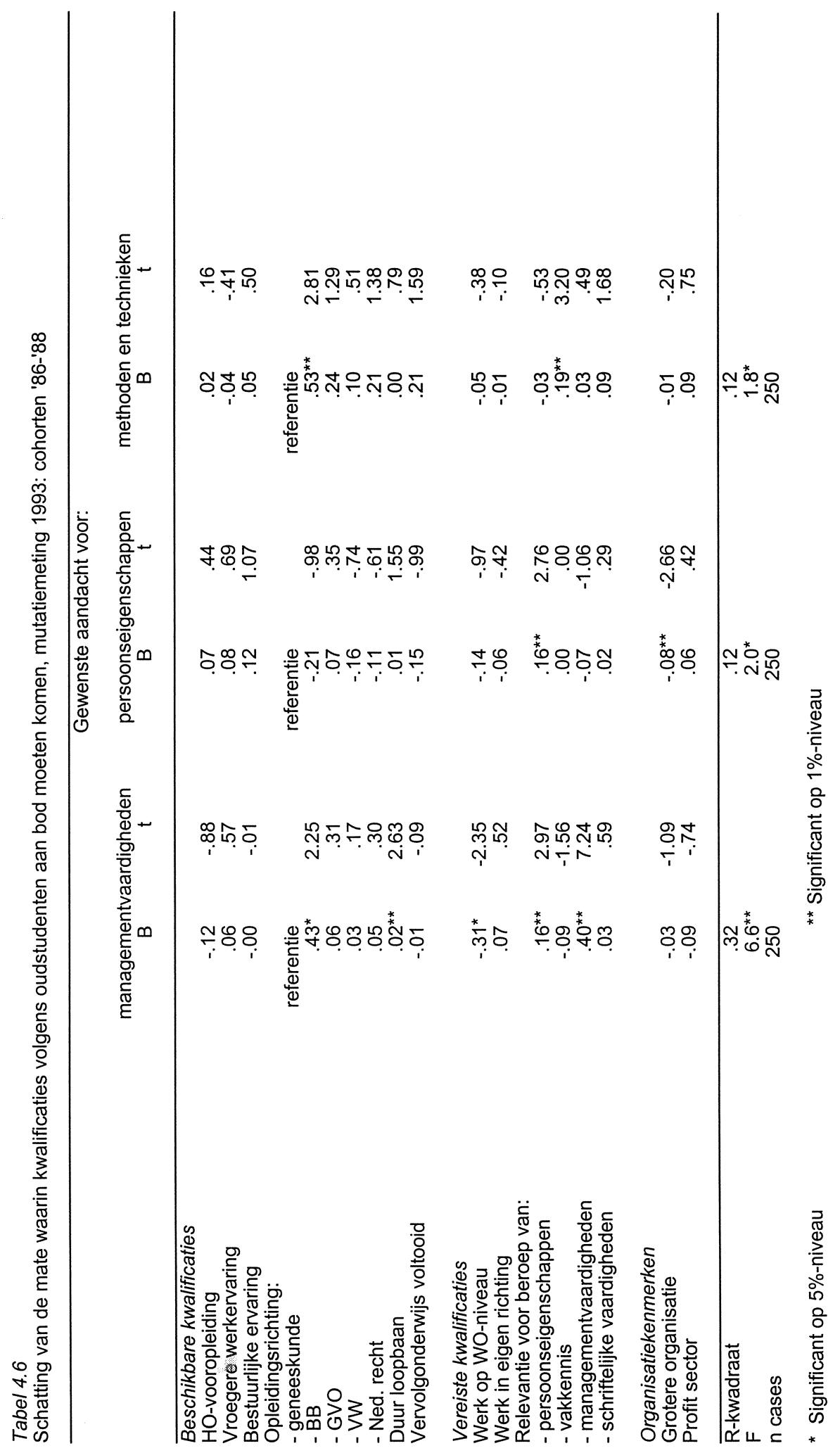




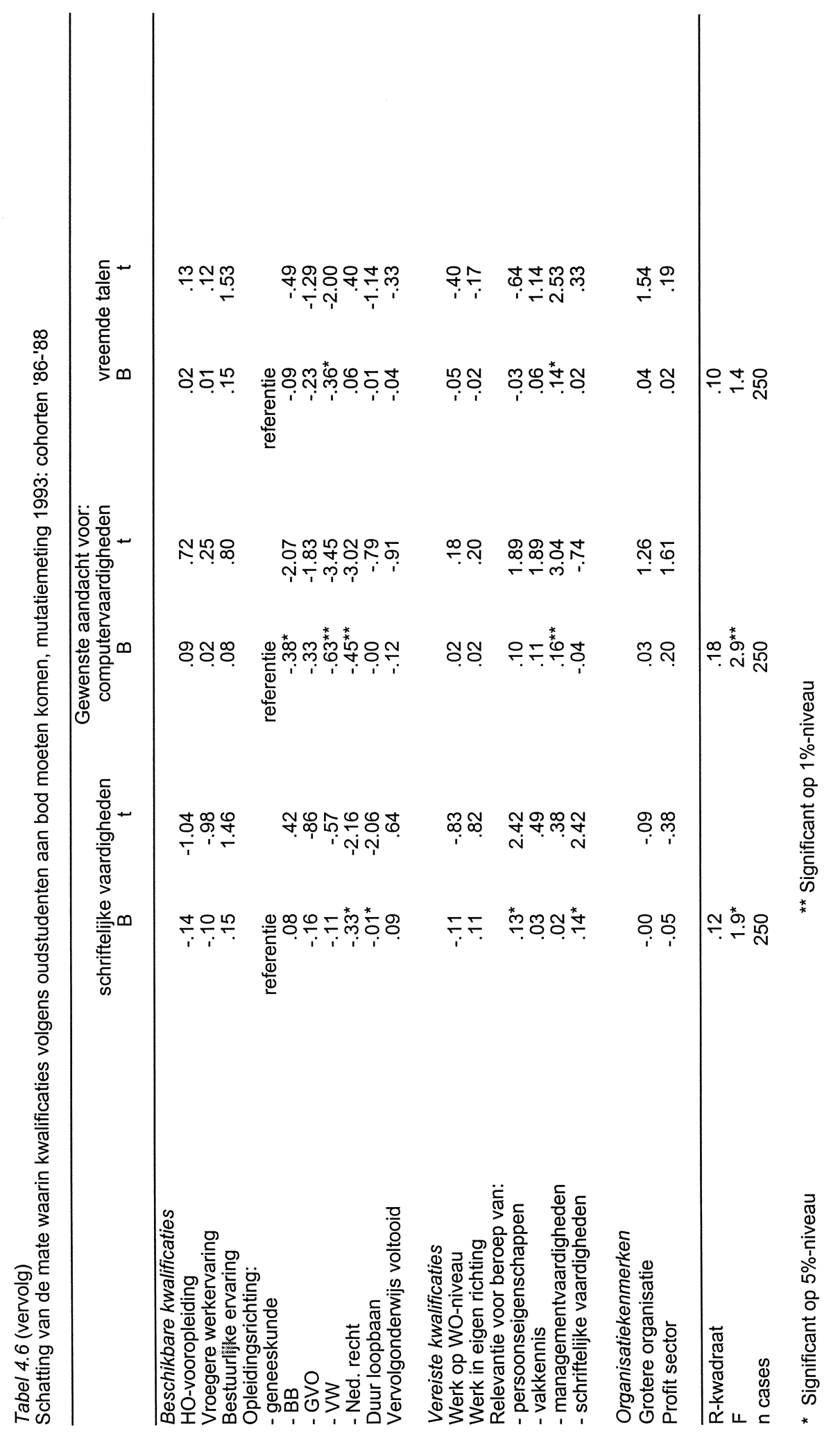




\section{Gewenste aandacht voor vreemde talen}

Tot slot laat tabel 4.6 zien dat oudstudenten VW, tenminste vergeleken met oudstudenten geneeskunde, vinden dat aan vreemde talen tijdens de opleiding best wat minder aandacht zou kunnen worden besteed dan thans het geval is. Naar de mening van oudstudenten die functies uitoefenen waarbij managementvaardigheden belangrijk zijn, mag aan de beheersing van vreemde talen best nog meer aandacht worden besteed tijdens de opleiding. 


\section{Ontwikkelingen in de intrede op de arbeidsmarkt tussen afstudeercohorten '90-'94}

In de voorgaande hoofdstukken stonden longitudinale ontwikkelingen in de loopbaan van een cohort (hoofdstuk 2 en 3 ) en de afstemming tussen de genoten opleiding en het werk dat oudstudenten gaandeweg hun loopbaan uitoefenen (hoofdstuk 4) centraal. In dit hoofdstuk staat niet de latere ontwikkeling van de loopbaan maar de intrede op de arbeidsmarkt centraal. In de eind 1995 - begin 1996 gehouden basismeting is nagegaan hoe de transitie van de opleiding naar de arbeidsmarkt is verlopen bij degenen die in kalenderjaar 1994 aan de UM zijn afgestudeerd ${ }^{9}$. Tabel 5.1 geeft een overzicht van de respons op deze basismeting, uitgesplitst naar faculteit. De tabel laat zien dat tweederde $(65 \%)$ van de afgestudeerden aan deze basismeting hebben meegewerkt en dat de respons onder afgestudeerde juristen duidelijk lager is dan onder afgestudeerden van de andere faculteiten.

Tabel 5.1

Respons basismeting 1995/1996, cohort '94

\begin{tabular}{lccc} 
& N afgestudeerden & n respondenten & respons \\
\hline FdG & 123 & 82 & $67 \%$ \\
FdGW & 428 & 312 & $73 \%$ \\
FdR & 222 & 108 & $49 \%$ \\
FdEW & 296 & 191 & $65 \%$ \\
Totaal UM & 1069 & 693 & $65 \%$ \\
\hline
\end{tabular}

In dit hoofdstuk worden de resultaten van deze basismeting afgezet tegen de resultaten van de vier hieraan voorafgaande basismetingen onder respectievelijk afstudeercohort '90, '91, '92 en '93. Hierdoor kan worden nagegaan hoe de transitie van studie naar werk zich in de eerste helft van de negentiger jaren heeft ontwikkeld. Deze ontwikkeling wordt aan de hand van een drietal indicatoren in kaart gebracht: de kans op werk, de zekerheid van het werk en de opleidingseisen die voor het werk worden gesteld.

De kans op werk wordt geïndiceerd door de werkloosheid op het moment van de enquête, dat wil zeggen in de maanden oktober-januari, hetgeen neerkomt op zo'n anderhalf jaar na het afstuderen (afhankelijk van de maand waarin men is afgestudeerd en de maand waarin men het enquêteformulier heeft ingevuld). De zekerheid

9. Over deze meting is per faculteit gerapporteerd in de vorm van een vertrouwelijke, statistisch gerichte faculteitsrapportage en een vertrouwelijke, facultaire management summary alsmede een vertrouwelijk samenvattend verslag ten behoeve van het College van Bestuur. 
van het werk wordt geïndiceerd door het procentuele aandeel van in loondienst werkende afgestudeerden dat een vaste aanstelling heeft. De functievereisten betreffen zowel het niveau als de richting van de opleiding die door de werkgever voor de vervulling van de functie wordt vereist. Het vereiste opleidingsniveau wordt geïndiceerd door het procentuele aandeel van banen waarvoor een academische opleiding is vereist en de vereiste opleidingsrichting door het procentuele aandeel van banen waarvoor de 'eigen' of een verwante opleiding wordt vereist (banen in het 'eigen' domein).

Naast de kans op werk, de zekerheid van het werk en de opleidingseisen die voor het werk worden gesteld, wordt aangegeven in welke regio de betaald-werkende afgestudeerden terecht zijn gekomen. Deze informatie laat zien in welke mate de UM afgestudeerden opleidt voor werkgevers in de regio, voor bedrijven en instellingen in de rest van Nederland of zelfs het buitenland. Is dat laatste het geval, dan heeft dit wellicht te maken met het actieve internationaliseringsbeleid van de UM. Met betrekking tot het werken in het buitenland, hoewel geografisch gezien vaak zeer nabij, dient te worden bedacht dat dit nog steeds met grote "sociaal-economische" barrières gepaard gaat. Daarbij komt dat men ook binnen de in Nederland gevestigde bedrijven of instellingen internationale functies kan bekleden. Het werken in de eigen regio zegt niet alleen iets over de bijdrage van de UM aan het intellectueel potentieel van de regionale beroepsbevolking maar ook iets over de werkgelegenheidssituatie in de eigen regio: bij onvoldoende geschikte banen in de eigen regio zijn afgestudeerden namelijk genoodzaakt om banen verder van huis te accepteren.

\section{Alle afgestudeerden}

Tabel 5.2 schetst de ontwikkeling van de arbeidsmarktpositie van de afstudeerjaargangen '90-'94 aan de hand van bovengenoemde indicatoren. Kenmerkend voor het beschouwde tijdvak is dat de gemiddelde jaarlijkse groei van het aantal baanopeningen voor nieuwkomers, ondanks de conjuncturele opleving, geen gelijke tred heeft kunnen houden met de omvangrijke gemiddelde jaarlijkse groei van het aantal afgestudeerden. Het moge duidelijk zijn dat de eerste helft van de jaren negentig niet de meest optimale periode was om de arbeidsmarkt te betreden. Zo schommelt de werkloosheid onder afgestudeerden van de UM in deze periode tussen zeven en tien procent. In 1995 is evenwel verbetering in deze situatie gekomen: de werkloosheid daalde licht.

De zekerheid van het werk is in de jaren $1992 \mathrm{t} / \mathrm{m} 1994$ licht afgenomen. In 1995 is ook hierin verbetering gekomen: het aandeel van vaste aanstellingen is sterk toegenomen.

Tegenover de in 1995 gedaalde werkloosheid en sterk toegenomen baanzekerheid 
staat dat de kans op een baan in het eigen beroependomein, na een sterke toename in 1994, het laatste jaar licht is gedaald.

Tabel 5.2

Ontwikkelingen arbeidsmarktpositie afgestudeerden UM, cohorten '90-'94

\begin{tabular}{lrrrrr}
\hline Afstudeercohort & $' 90$ & $' 91$ & $' 92$ & $' 93$ & $' 94$ \\
Aantal afgestudeerden & 510 & 652 & 784 & 894 & 1069 \\
\hline Situatie in & 1991 & 1992 & 1993 & 1994 & 1995 \\
Werkloos & $9 \%$ & $7 \%$ & $9 \%$ & $10 \%$ & $7 \%$ \\
Vaste aanstellingen & $*$ & $44 \%$ & $42 \%$ & $40 \%$ & $48 \%$ \\
Zelfstandigen & $3 \%$ & $2 \%$ & $3 \%$ & $2 \%$ & $2 \%$ \\
Functies op wo-nivo & $79 \%$ & $75 \%$ & $66 \%$ & $66 \%$ & $55 \%$ \\
Functies in eigen domein & $*$ & $71 \%$ & $68 \%$ & $79 \%$ & $76 \%$ \\
\hline Bron: & & & & &
\end{tabular}

Bron:

- aantal afgestudeerden (dienst Studentenzaken UM);

- indicatoren arbeidsmarktpositie (ROA).

Toelichting:

* Vergelijkbare cijfers niet beschikbaar.

Voor het berekenen van het werkloosheidspercentage is het aantal geregistreerde werkloze afgestudeerden uitgedrukt als percentage van de afgestudeerden die tot de beroepsbevolking behoren. De andere percentages in tabel 5.2 betreffen uitsluitend betaald-werkende afgestudeerden.

De meest opvallende ontwikkeling vormt evenwel het over de gehele periode 19911995 gestaag toenemende aandeel van afgestudeerden dat moet uitwijken naar functies beneden hun opleidingsniveau.

Tabel 5.3

Afgestudeerden UM naar werkregio, cohorten '90-'94

\begin{tabular}{lrrrrr}
\hline Afstudeercohort & $' 90$ & $' 91$ & $' 92$ & $' 93$ & $' 94$ \\
\hline Werkregio in & 1991 & 1992 & 1993 & 1994 & 1995 \\
Limburg & $46 \%$ & $47 \%$ & $41 \%$ & $35 \%$ & $34 \%$ \\
Overig Nederland & $49 \%$ & $50 \%$ & $57 \%$ & $62 \%$ & $61 \%$ \\
Buitenland & $5 \%$ & $4 \%$ & $3 \%$ & $4 \%$ & $5 \%$ \\
Totaal n (= 100\%) & 297 & 414 & 439 & 448 & 600 \\
\hline
\end{tabular}

Het ROA verwacht dat in de tweede helft van de jaren negentig de nationale arbeidsmarktsituatie voor hoger opgeleiden zal verbeteren. Dit als gevolg van een relatief lage arbeidsmarktinstroom van afgestudeerden en een relatieve hoge vervangingsgraad als gevolg van de stijgende arbeidsmarktuitstroom van werkenden. De gunstige vraag-aanbod-verhoudingen impliceren wellicht dat de afgestudeerden in de toekomst minder vaak in banen beneden hun opleidingniveau zullen terechtkomen (ROA, De arbeidsmarkt naar opleiding en beroep tot 2000, Maastricht, 
1995).

Tabel 5.3 laat zien dat in de jaren $1992 \mathrm{t} / \mathrm{m} 1994$ steeds meer afgestudeerden van de UM buiten Limburg zijn gaan werken. Vanaf 1994 stabiliseert het aandeel van zowel de provincie Limburg als de rest van Nederland in de werkgelegenheid van Maastrichtse afgestudeerden.

\section{Basisartsen}

Tabel 5.4 schetst de ontwikkeling van de arbeidsmarktpositie van de in 1990-1994 afgestudeerde basisartsen. De tabel laat zien dat de arbeidsmarktpositie van basisartsen in de eerste helft van de jaren negentig wordt gekenmerkt door een zeer grote en stabiele kans op werk.

Tabel 5.4

Indicatoren arbeidsmarktpositie afgestudeerden FdG, cohorten '90-'94

\begin{tabular}{lrrrrr}
\hline Afstudeercohort & $' 90$ & $' 91$ & $' 92$ & $' 93$ & $' 94$ \\
Aantal afgestudeerden & 113 & 123 & 84 & 122 & 123 \\
\hline Situatie in & 1991 & 1992 & 1993 & 1994 & 1995 \\
Werkloos & $0 \%$ & $0 \%$ & $0 \%$ & $3 \%$ & $0 \%$ \\
Vaste aanstellingen & $*$ & $18 \%$ & $11 \%$ & $9 \%$ & $21 \%$ \\
Functies op wo-nivo & $99 \%$ & $100 \%$ & $98 \%$ & $99 \%$ & $99 \%$ \\
Functies in eigen domein & $*$ & $88 \%$ & $86 \%$ & $87 \%$ & $89 \%$ \\
\hline Bron: & & & & & \\
\hline
\end{tabular}

Bron:

- aantal afgestudeerden (dienst Studentenzaken UM);

- indicatoren arbeidsmarktpositie (ROA).

Toelichting:

* Vergelijkbare cijfers niet beschikbaar.

Voor het berekenen van het werkloosheidspercentage is het aantal geregistreerde werkloze afgestudeerden uitgedrukt als percentage van de afgestudeerden die tot de beroepsbevolking behoren. De andere percentages in de tabel betreffen uitsluitend betaald-werkende afgestudeerden.

De baanzekerheid is echter laag. Deze is in de jaren 1992-1994 bovendien verder afgenomen. Hierin is in 1995 evenwel verbetering gekomen; het aandeel met vaste aanstelling is dat jaar sterk toegenomen.

Verder wordt de arbeidsmarktpositie van basisartsen in de eerste helft van de jaren negentig gekenmerkt door een zeer hoog en stabiel aandeel dat qua niveau en richting passend werk heeft. In 1995 is het zeer hoge aandeel dat werk in het eigen beroependomein heeft zelfs nog iets gestegen.

Voor de tweede helft van de jaren negentig zijn volgens het ROA de nationale arbeidsmarktperspectieven van de opleiding geneeskunde gunstig. Dit vanwege de stabiele omvang van de arbeidsmarktinstroom in combinatie met vooral de erg hoge 
vervangingsvraag (ROA, De arbeidsmarkt naar opleiding en beroep tot 2000 , Maastricht, 1995).

De regionale ontwikkeling in de werkgelegenheid van Maastrichtse basisartsen in de eerste helft van de jaren negentig wordt t/m 1994 gekenmerkt door een gestaag toenemend aandeel van basisartsen op de landelijke arbeidsmarkt en een gestaag dalend aandeel van in Limburg en in het buitenland $(t / m$ 1993) werkende basisartsen. Tabel 5.5 geeft hiervan een beeld. Aan het gestaag toenemend accepteren van banen in provincies buiten Limburg is in 1995 een einde gekomen: het aandeel van de landelijke arbeidsmarkt is dat jaar licht afgenomen en het aandeel van de Limburgse arbeidsmarkt licht gestegen. Het aandeel van in het buitenland werkende basisartsen neemt vanaf 1994 toe.

Tabel 5.5

Afgestudeerden FdG naar werkregio, cohorten '90-'94

\begin{tabular}{lrrrrr}
\hline Afstudeercohort & $' 90$ & $' 91$ & $' 92$ & $' 93$ & $' 94$ \\
\hline Werkregio in & 1991 & 1992 & 1993 & 1994 & 1995 \\
Limburg & $47 \%$ & $45 \%$ & $46 \%$ & $37 \%$ & $39 \%$ \\
Overig Nederland & $43 \%$ & $49 \%$ & $55 \%$ & $60 \%$ & $56 \%$ \\
Buitenland & $10 \%$ & $6 \%$ & $0 \%$ & $3 \%$ & $5 \%$ \\
Totaal n (= 100\%) & 81 & 80 & 55 & 67 & 80 \\
\hline
\end{tabular}

\section{Gezondheidswetenschappers}

Tabel 5.6 schetst de ontwikkeling van de arbeidsmarktpositie van gezondheidswetenschappers, afstudeerjaargangen '90-'94. De tabel laat zien dat de werkloosheid, na enkele jaren te zijn toegenomen, het laatste jaar sterk is gedaald en wel naar het peil van 1992.

De baanzekerheid blijkt in de beschouwde periode licht te fluctueren en is het laatste jaar iets toegenomen. Het aandeel van afgestudeerden dat werk heeft gevonden in het eigen domein is de laatste twee jaar duidelijk hoger dan in de twee voorafgaande jaren.

Een duidelijk minpunt in de afgelopen vier jaren betreft het gestaag toegenomen aandeel van gezondheidswetenschappers dat een baan heeft beneden hun opleidingsniveau. Deze toename is vooral het laatste jaar erg groot geweest. Hierbij speelt ongetwijfeld een rol dat de studie gezondheidswetenschappen, met name verplegingswetenschap, vaak door deeltijdstudenten (19\%) wordt gevolgd, die na het afstuderen blijven werken in hun vroegere baan op MBO- of HBO-niveau. 
Tabel 5.6

Indicatoren arbeidsmarktpositie afgestudeerden FdGW, cohorten '90-'94

\begin{tabular}{|c|c|c|c|c|c|}
\hline Afstudeercohort & '90 & '91 & '92 & '93 & '94 \\
\hline Aantal afgestudeerden & 174 & 258 & 377 & 391 & 428 \\
\hline Situatie in & 1991 & 1992 & 1993 & 1994 & 1995 \\
\hline $\begin{array}{l}\text { Werkloos } \\
\text { Vaste aanstellingen } \\
\text { Functies op wo-nivo } \\
\text { Functies in eigen domein }\end{array}$ & $\begin{array}{r}9 \% \\
* \\
68 \% \\
*\end{array}$ & $\begin{array}{r}8 \% \\
42 \% \\
68 \% \\
56 \%\end{array}$ & $\begin{array}{l}10 \% \\
46 \% \\
60 \% \\
54 \%\end{array}$ & $\begin{array}{l}12 \% \\
43 \% \\
52 \% \\
77 \%\end{array}$ & $\begin{array}{r}8 \% \\
48 \% \\
36 \% \\
73 \%\end{array}$ \\
\hline \multicolumn{6}{|c|}{$\begin{array}{l}\text { Bron: } \\
\text { - aantal afgestudeerden (dienst Studentenzaken UM); } \\
\text { - indicatoren arbeidsmarktpositie (ROA). } \\
\text { Toelichting: } \\
\text { *Vergelijkbare cijfers niet beschikbaar. } \\
\text { Voor het berekenen van het werkloosheidspercentage is het aantal geregistreerde werkloze } \\
\text { afgestudeerden uitgedrukt als percentage van de afgestudeerden die tot de beroepsbevolking } \\
\text { behoren. De andere percentages in de tabel betreffen uitsluitend betaald-werkende afgestu- } \\
\text { deerden. }\end{array}$} \\
\hline \multicolumn{6}{|c|}{$\begin{array}{l}\text { Over de arbeidsmarktperspectieven voor de komende jaren van deze nog relatief } \\
\text { jonge opleiding kan het ROA nog weinig met zekerheid zeggen omdat deze catego- } \\
\text { rie bij de prognoses niet afzonderlijk wordt onderscheiden. In ieder geval wordt } \\
\text { landelijk voor afgestudeerden van medische opleidingen een relatief groot aantal } \\
\text { baanopeningen verwacht, mede vanwege de hoge uitbreidingsvraag als gevolg van } \\
\text { de toenemende vergrijzing van de bevolking (ROA, De arbeidsmarkt naar opleiding } \\
\text { en beroep tot } 2000 \text {, Maastricht, 1995). Wellicht gaat dit ook op voor de sterk met de } \\
\text { medische beroepen samenhangende functies voor gezondheidswetenschappers. }\end{array}$} \\
\hline \multicolumn{6}{|c|}{$\begin{array}{l}\text { Tabel } 5.7 \\
\text { Afgestudeerden FdGW naar werkregio, cohorten '90-'94 }\end{array}$} \\
\hline Afstudeercohort & '90 & '91 & '92 & '93 & '94 \\
\hline Werkregio in & 1991 & 1992 & 1993 & 1994 & 1995 \\
\hline $\begin{array}{l}\text { Limburg } \\
\text { Overig Nederland } \\
\text { Buitenland }\end{array}$ & $\begin{array}{r}33 \% \\
64 \% \\
3 \%\end{array}$ & $\begin{array}{r}35 \% \\
64 \% \\
1 \%\end{array}$ & $\begin{array}{r}35 \% \\
62 \% \\
2 \%\end{array}$ & $\begin{array}{r}27 \% \\
70 \% \\
3 \%\end{array}$ & $\begin{array}{r}30 \% \\
68 \% \\
3 \%\end{array}$ \\
\hline Totalal $n(=100 \%)$ & 112 & 180 & 221 & 205 & 263 \\
\hline
\end{tabular}

Tabel 5.7 laat zien dat gezondheidswetenschappers voor hun werkgelegenheid veel meer zijn aangewezen op de landelijke arbeidsmarkt dan op de Limburgse arbeidsmarkt. Tot en met 1993 kwam ongeveer eenderde van de gezondheidswetenschappers terecht op de Limburgse arbeidsmarkt en tweederde op de landelijke arbeidsmarkt. In 1994 nam het aandeel van de landelijke arbeidsmarkt licht toe. Aan deze lichte stijging is in 1995 een einde gekomen: het laatste jaar is het aandeel van 
Limburg weer licht toegenomen (na een kleine daling in 1994).

Juristen

Tabel 5.8 schetst de ontwikkeling van de arbeidsmarktpositie van de afgestudeerde juristen, jaargangen '90-'94. De tabel laat zien dat de kans op werk van juristen na 1991 sterk is verbeterd, getuige de grote daling van de werkloosheid in 1992. De sterke daling in 1992 hangt samen met de relatief omvangrijke eerste lichting afgestudeerden van de avondopleiding Nederlands recht (hun aandeel in de uitstroom van cohort ' 91 bedroeg $31 \%$ ), waarvan slechts $3 \%$ werkloos was. Sindsdien geeft de werkloosheid een fluctuerend verloop te zien. Ten opzichte van het voorafgaande jaar is de werkloosheid in 1995 enigszins verslechterd.

Tabel 5.8

Indicatoren arbeidsmarktpositie afgestudeerden FdR, cohorten '90-'94

\begin{tabular}{lrrrrr}
\hline Afstudeercohort & $' 90$ & $' 91$ & $' 92$ & 193 & $' 94$ \\
Aantal afgestudeerden & 165 & 173 & 165 & 189 & 222 \\
\hline Situatie in & 1991 & 1992 & 1993 & 1994 & 1995 \\
Werkloos & $21 \%$ & $7 \%$ & $12 \%$ & $8 \%$ & $10 \%$ \\
Vaste aanstellingen & $*$ & $59 \%$ & $46 \%$ & $47 \%$ & $51 \%$ \\
Functies op wo-nivo & $73 \%$ & $64 \%$ & $64 \%$ & $78 \%$ & $72 \%$ \\
Functies in eigen domein & $*$ & $72 \%$ & $77 \%$ & $80 \%$ & $75 \%$ \\
\hline
\end{tabular}

Bron:

- aantal afgestudeerden (dienst Studentenzaken UM);

- indicatoren arbeidsmarktpositie (ROA)

Toelichting:

* Vergelijkbare cijfers niet beschikbaar.

Voor het berekenen van het werkloosheidspercentage is het aantal geregistreerde werkloze afgestudeerden uitgedrukt als percentage van de afgestudeerden die tot de beroepsbevolking behoren. De andere percentages in de tabel betreffen uitsluitend betaald-werkende afgestudeerden.

Niet alleen de lage werkloosheid maar ook de grote baanzekerheid in 1992 hangt samen met de relatief omvangrijke eerste lichting afgestudeerden van de avondopleiding Nederlands recht, waarvan $84 \%$ een vaste aanstelling had. De zekerheid van het werk is de afgelopen twee jaar toegenomen.

Het aandeel van afgestudeerden met een baan op wo-niveau is in 1995 weliswaar afgenomen, maar ligt nog steeds op een vergelijkbaar hoog niveau als in 1991, hoewel het relatief hoge niveau van 1994 niet meer wordt bereikt.

De kans dat het werk van juristen aansluit bij hun opleidingsrichting is tot en met 1994 gestaag toegenomen met een lichte terugval in 1995.

Gezien de licht gestegen werkloosheid en de lichte terugval in het aandeel van 
functies die passen bij de gevolgde opleidingsrichting, is het de vraag of het jaar 1995 het begin inluidt van een minder gunstige periode. In de tweede helft van de jaren negentig wordt namelijk door het ROA landelijk een erg hoge arbeidsmarktinstroom van afgestudeerde juristen verwacht, waardoor hun arbeidsmarktperspectief onder druk zal komen te staan (ROA, De arbeidsmarkt naar opleiding en beroep tot 2000, Maastricht, 1995).

Wat de werkregio betreft, daalt het aandeel juristen dat in Limburg gaat werken vanaf 1992 gestaag met als gevolg dat thans meer juristen buiten dan binnen de provincie Limburg terecht komen. Tabel 5.9 geeft hiervan een beeld. Het aandeel dat in het buitenland gaat werken is het laatste jaar toegenomen en ligt weer op het relatief hoge peil van 1991. De hoge piek in het aandeel van Limburg in 1992 hangt samen met de relatief omvangrijke eerste lichting afgestudeerden van de avondopleiding Nederlands recht (hun aandeel in de uitstroom van cohort '91 bedroeg $31 \%$ ), die voor $96 \%$ in Limburg zijn gaan werken.

Tabel 5.9

Afgestudeerden FdR naar werkregio, cohorten '90-'94

\begin{tabular}{lrrrrr}
\hline Afstudeercohort & '90 & $' 91$ & $' 92$ & '93 & '94 \\
\hline Werkregio in & 1991 & 1992 & 1993 & 1994 & 1995 \\
Limburg & $62 \%$ & $76 \%$ & $56 \%$ & $48 \%$ & $43 \%$ \\
Overig Nederland & $32 \%$ & $24 \%$ & $43 \%$ & $52 \%$ & $53 \%$ \\
Buitenland & $6 \%$ & $0 \%$ & $1 \%$ & $0 \%$ & $4 \%$ \\
Totaal n (= 100\%) & 65 & 91 & 79 & 88 & 93 \\
\hline
\end{tabular}

\section{Economen}

Tabel 5.10 laat zien dat de werkloosheid onder economen na 1991 op een hoger peil is komen te liggen. De werkloosheid is in 1995 ten opzichte van het relatief ongunstige jaar 1994 echter gehalveerd.

$\mathrm{Na}$ een lichte daling in de periode 1992-1994, is de baanzekerheid in 1995 weer toegenomen en wel tot bijna het relatief hoge peil van 1992.

De in 1995 sterk toegenomen kans op werk en zekerheid van het werk laat onverlet dat in 1995 geen einde is gekomen aan de gestaag toenemende onderbenutting. In 1995 is bovendien de kans op werk binnen het eigen beroependomein verder gedaald.

Hoewel volgens ROA-prognoses de landelijke arbeidsmarktinstroom van afgestudeerden econo(metr)ie en accountancy voorlopig nog wel hoog zal blijven, wordt 
verwacht dat deze zal achterbijven bij het aantal baanopeningen voor nieuwkomers met deze opleidingsachtergrond. De arbeidsmarktperspectieven van afgestudeerde econo(metr)isten en accountants voor de tweede helft van de jaren negentig zijn bijgevolg redelijk gunstig (ROA, De arbeidsmarkt naar opleiding en beroep tot 2000 , Maastricht, 1995).

Tabel 5.10

Indicatoren arbeidsmarktpositie afgestudeerden FdEWB, cohorten '90-'94

\begin{tabular}{|c|c|c|c|c|c|}
\hline Afstudeercohort & '90 & '91 & '92 & '93 & '94 \\
\hline Aantal afgestudeerden & 58 & 98 & 158 & 192 & 296 \\
\hline Situatie in & 1991 & 1992 & 1993 & 1994 & 1995 \\
\hline $\begin{array}{l}\text { Werkloos } \\
\text { Vaste aanstellingen } \\
\text { Functies op wo-nivo } \\
\text { Functies in eigen domein }\end{array}$ & $\begin{array}{r}2 \% \\
* \\
79 \% \\
*\end{array}$ & $\begin{array}{r}9 \% \\
60 \% \\
73 \% \\
84 \%\end{array}$ & $\begin{array}{r}6 \% \\
51 \% \\
66 \% \\
86 \%\end{array}$ & $\begin{array}{l}15 \% \\
49 \% \\
60 \% \\
75 \%\end{array}$ & $\begin{array}{r}7 \% \\
57 \% \\
55 \% \\
73 \%\end{array}$ \\
\hline \multicolumn{6}{|c|}{$\begin{array}{l}\text { Bron: } \\
\text { - aantal afgestudeerden (dienst Studentenzaken UM); } \\
\text { - indicatoren arbeidsmarktpositie (ROA). } \\
\text { Toelichting: } \\
\text { *Vergelijkbare cijfers niet beschikbaar. } \\
\text { Voor het berekenen van het werkloosheidspercentage is het aantal geregistreerde werkloze } \\
\text { afgestudeerden uitgedrukt als percentage van de afgestudeerden die tot de beroepsbevolking } \\
\text { behoren. De andere percentages in de tabel betreffen uitsluitend betaald-werkende afgestu- } \\
\text { deerden. }\end{array}$} \\
\hline \multicolumn{6}{|c|}{$\begin{array}{l}\text { Vergeleken met het begin van de jaren negentig is de arbeidsmarkt van Maas- } \\
\text { trichtse economen aanzienlijk landelijker geworden: het aandeel van de provincie } \\
\text { Limburg is gestaag gedaald met als gevolg dat vanaf } 1993 \text { meer dan de helft van de } \\
\text { Maastrichtse economen op de landelijke arbeidsmarkt terecht is gekomen. Het } \\
\text { laatste jaar heeft de toename van de buitenlandse arbeidsmarkt, die na de sterke } \\
\text { daling van } 1993 \text { op gang is gekomen, zich niet verder doorgezet. }\end{array}$} \\
\hline \multicolumn{6}{|c|}{$\begin{array}{l}\text { Tabel } 5.11 \\
\text { Afgestudeerden FdEWB naar werkregio, cohorten '90-'94 }\end{array}$} \\
\hline Afstudeercohort & '90 & '91 & '92 & '93 & '94 \\
\hline Werkregio in & 1991 & 1992 & 1993 & 1994 & 1995 \\
\hline $\begin{array}{l}\text { Limburg } \\
\text { Overig Nederland } \\
\text { Buitenland }\end{array}$ & $\begin{array}{r}56 \% \\
41 \% \\
3 \%\end{array}$ & $\begin{array}{l}41 \% \\
46 \% \\
13 \%\end{array}$ & $\begin{array}{r}37 \% \\
57 \% \\
6 \%\end{array}$ & $\begin{array}{r}36 \% \\
55 \% \\
9 \%\end{array}$ & $\begin{array}{r}35 \% \\
57 \% \\
8 \%\end{array}$ \\
\hline Totaal $\mathrm{n}(=100 \%)$ & 39 & 63 & 84 & 88 & 164 \\
\hline
\end{tabular}



$\ldots$ 


\title{
Bijlage 1 \\ Publicaties in het kader van de Arbeidsmarktscanner Universiteit Maastricht
}

\author{
1989
}

Dam, J.W. van, J.A.M. Heijke, G.W.M. Ramaekers (1989), Ontwerp van een arbeidsmarktscanner voor academici, ROA-R-1989/3, Maastricht.

1990

Ramaekers, G.W.M., J.A.M. Heijke (1990), Proefonderzoek arbeidsmarktscanner afgestudeerden Rijksuniversiteit Limburg, ROA-W-1990/3, Maastricht.

1991

Lodder, B.J.H., P.E.J. van de Loo, G.W.M. Ramaekers, R.K.W. van der Velden (1991), Arbeidsmarktindicatoren ten behoeve van het emancipatiebeleid van de Rijksuniversiteit Limburg, ROA-R-1991/7, Maastricht.

Ramaekers, G.W.M., J.A.M. Heijke (1991), Arbeidsmarktscanner Rijksuniversiteit Limburg: Afgestudeerden 1986-1989, ROA-R-1991/6, Maastricht.

1992

Heijke, J.A.M., G.W.M. Ramaekers (1992), Labour Market Position of University of Limburg Graduates, ROA-RM-1992/2E, Maastricht.

Heijke, J.A.M., G.W.M. Ramaekers (1992), De arbeidsmarktpositie van afgestudeerden van de Rijksuniversiteit Limburg 1986-1989, op basis van de arbeidsmarktscanner, in: Tijdschrift voor Hoger Onderwijs, jrg. 10, nr. 3, blz. 168-188.

Lodder, B.J.H., P.E.J. van de Loo, G.W.M. Ramaekers, R.K.W. van der Velden (1992), Sex differences in the labour market position of young graduates, in: $\mathrm{Tj}$. Plomp, J.M. Pieters, A. Feteris (ed), European Conference on Educational Research: Book of Summaries. Volume 3, pp. 1057-1059, University of Twente, June 1992, Enschede.

Ramaekers, G.W.M., J.A.M. Heijke (1992), De arbeidsmarktpositie van aan de RL afgestudeerde basisartsen, in: Kozijn, april '92, nr. 6, blz. 12-13. 
Borghans, L., G.W.M. Ramaekers (1993), De doorstroom van Limburgse basisartsen naar medische beroepsopleidingen, ROA-W-1993/1.

Borghans, L., G. Ramaekers (1993), Maastrichtse basisartsen op zoek naar een opleidingsplaats, in: Mediscoop, jrg. 1, nr. 3, blz. 6-7.

Ramaekers, G.W.M., J.A.M. Heijke (1993), Arbeidsmarktscanner Rijksuniversiteit Limburg: Basismeting cohort '90, ROA-R-1993/1, Maastricht.

Ramaekers, G.W.M., J.A.M. Heijke (1993), Arbeidsmarktscanner Rijksuniversiteit Limburg: Basismeting cohort '91, ROA-R-1993/13, Maastricht.

Ramaekers, G.W.M., J.A.M. Heijke (1993), Arbeidsmarktonderzoek onder Limburgse economen, in: Reliëf, jrg. 5, nr. 9, blz. 9.

1994

Borghans, L., G.W.M. Ramaekers (1994), De doorstroom van Limburgse basisartsen naar medische beroepsopleidingen, in: Pedagogische Studiën. Tijdschrift voor onderwijskunde en opvoedkunde, jrg. 71, nr. 5, blz. 340-351.

Ramaekers, G.W.M. (1994), Arbeidsmarktscanner Rijksuniversiteit Limburg: Basismeting cohort '92, ROA-R-1994/7, Researchcentrum voor Onderwijs en Arbeidsmarkt, Maastricht.

Ramaekers, G.W.M. (1994), Een schets van de arbeidsmarktpositie van afgestudeerden Beleid en Beheer van de Gezondheidszorg, in: Nederlands Onafhankelijk Tijdschrift Alumnivereniging Beleid en Beheer van de Gezondheidszorg, jrg. 3, nr. 1, blz. 5-7.

Ramaekers, G.W.M. (1994), Een schets van de arbeidsmarktpositie van verplegingswetenschappers, in: Met Verve. Verenigingsblad voor Verplegingswetenschappers, jrg. 1, nr. 1, blz. 18-21.

Ramaekers, G.W.M. (1994), Arbeidsmarktonderzoek onder afgestudeerden Geestelijke Gezondheidkunde, in: Psychoskoop, jrg. 5, nr. 2, blz. 34-37.

\section{5}

Faculteitsrapportage WO-Scanner 1994, afstudeerjaargang '93, Rijksuniversiteit Limburg, Faculteit der Economische Wetenschappen en Bedrijfskunde, vertrouwe- 
lijke rapportage.

Faculteitsrapportage WO-Scanner 1994, afstudeerjaargang '93, Rijksuniversiteit Limburg, Faculteit der Geneeskunde, vertrouwelijke rapportage.

Faculteitsrapportage WO-Scanner 1994, afstudeerjaargang '93, Rijksuniversiteit Limburg, Faculteit der Gezondheidswetenschappen, vertrouwelijke rapportage.

Faculteitsrapportage WO-Scanner 1994, afstudeerjaargang '93, Rijksuniversiteit Limburg, Faculteit der Rechtsgeleerdheid, vertrouwelijke rapportage.

Ramaekers, G.W.M. (1995), Arbeidsmarktscanner 1994 Rijksuniversiteit Limburg, kernciffers basismeting cohort '93, vertrouwelijke rapportage.

Ramaekers, G.W.M., J.A.M. Heijke (1995), Discrepancies in the labour market for RL-educated economists, in: W.H. Gijselaers, et al (eds), Educational Innovation in Economics and Business Administration. The case of Problem-Based Learning, Kluwer Academic Publishers, Dordrecht/Boston/London, pp. 370-381.

\section{6}

Faculteitsrapportage WO-Scanner 1995, afstudeerjaargang '94, Rijksuniversiteit Limburg, Faculteit der Economische Wetenschappen en Bedrijfskunde, vertrouwelijke rapportage.

Faculteitsrapportage WO-Scanner 1995, afstudeerjaargang '94, Rijksuniversiteit Limburg, Faculteit der Geneeskunde, vertrouwelijke rapportage.

Faculteitsrapportage WO-Scanner 1995, afstudeerjaargang '94, Rijksuniversiteit Limburg, Faculteit der Gezondheidswetenschappen, vertrouwelijke rapportage.

Faculteitsrapportage WO-Scanner 1995, afstudeerjaargang '94, Rijksuniversiteit Limburg, Faculteit der Rechtsgeleerdheid, vertrouwelijke rapportage.

Heijke, J.A.M., G.W.M. Ramaekers (1996), The Knowledge and Skills of Economics Graduates and their Significance on the Labour Market, Paper presented at the Conference of the European Association of Labour Economists, 19-22 September 1996, Chania, Crete.

Ramaekers, G.W.M. (1996), Arbeidsmarktscanner 1995 Rijksuniversiteit Limburg, kerncijfers basismeting cohort '94, vertrouwelijke rapportage.

Ramaekers, G.W.M. (1996), Beroepsrelevante kwalificaties van economen, in: 
Onderzoek van Onderwijs, jrg. 25, nr. 2, blz. 35-37.

Ramaekers, G.W.M. (1996), Economen in het MKB, Researchcentrum voor Onderwijs en Arbeidsmarkt, vertrouwelijke rapportage.

Ramaekers, G.W.M. (1996), Management Summary WO-Scanner 1995, Faculteit der Economische Wetenschappen en Bedrijfskunde, Rijksuniversiteit Limburg, vertrouwelijke rapportage.

Ramaekers, G.W.M. (1996), Management Summary WO-Scanner 1995, Faculteit der Geneeskunde, Rijksuniversiteit Limburg, vertrouwelijke rapportage.

Ramaekers, G.W.M. (1996), Management Summary WO-Scanner 1995, Faculteit der Gezondheidswetenschappen, Rijksuniversiteit Limburg, vertrouwelijke rapportage.

Ramaekers, G.W.M. (1996), Management Summary WO-Scanner 1995, Faculteit der Rechtsgeleerdheid, Rijksuniversiteit Limburg, vertrouwelijke rapportage.

Ramaekers, G.W.M. (1996), ROA onderzoekt afgestudeerde economen van de Erasmus Universiteit Rotterdam, Katholieke Universiteit Brabant en Universiteit Maastricht, in: Reliëf, jrg. 8, nr. 7, blz. 6.

Ramaekers, G.W.M. (1996), Start als zelfstandig ondernemer door hoger opgeleiden in de regio Maastricht en overig Zuid-Limburg, Researchcentrum voor Onderwijs en Arbeidsmarkt, vertrouwelijke rapportage.

Ramaekers, G.W.M. (1996), WO-scanner economie 1994. Basismeting cohort '93, ROA-R-1996/1, Researchcentrum voor Onderwijs en Arbeidsmarkt, Maastricht.

Ramaekers, G.W.M. (1996), WO-scanner economie 1995. Basismeting cohort '94, ROA-R-1996/15, Researchcentrum voor Onderwijs en Arbeidsmarkt, Maastricht.

\section{7}

Faculteitsrapportage WO-Scanner 1996, Afstudeerjaargang '95, Universiteit Maastricht, Faculteit der Economische Wetenschappen en Bedrijfskunde, vertrouwelijke rapportage.

Faculteitsrapportage WO-Scanner 1996, Afstudeerjaargang '95, Universiteit Maastricht, Faculteit der Geneeskunde, vertrouwelijke rapportage.

Faculteitsrapportage WO-Scanner 1996, Afstudeerjaargang '95, Universiteit Maas- 
tricht, Faculteit der Gezondheidswetenschappen, vertrouwelijke rapportage.

Faculteitsrapportage WO-Scanner 1996, Afstudeerjaargang '95, Universiteit Maastricht, Faculteit der Rechtsgeleerdheid, vertrouwelijke rapportage.

Ramaekers, G.W.M. (1997), Arbeidsmarktscanner 1996 Universiteit Maastricht, Kerncijfers basismeting cohort '95, Management Summary ten behoeve van het College van Bestuur, vertrouwelijke rapportage.

Ramaekers, G.W.M. (1997), Kernciffers WO-Scanner 1996, Faculteit der Cultuurwetenschappen, Universiteit Maastricht, vertrouwelijke rapportage.

Ramaekers, G.W.M. (1997), Management Summary WO-Scanner 1996, Faculteit der Economische Wetenschappen en Bedriffskunde, Universiteit Maastricht, vertrouwelijke rapportage.

Ramaekers, G.W.M. (1997), Management Summary WO-Scanner 1996, Faculteit der Geneeskunde, Universiteit Maastricht, vertrouwelijke rapportage.

Ramaekers, G.W.M. (1996), Management Summary WO-Scanner 1996, Faculteit der Gezondheidswetenschappen, Universiteit Maastricht, vertrouwelijke rapportage.

Ramaekers, G.W.M. (1996), Management Summary WO-Scanner 1996, Faculteit der Rechtsgeleerdheid, Universiteit Maastricht, vertrouwelijke rapportage.

Ramaekers, G.W.M. (1997), WO-monitor economie 1996. Basismeting cohort '95, ROA-R-1997/4, Researchcentrum voor Onderwijs en Arbeidsmarkt, Maastricht. 
$\ldots \ldots$ 


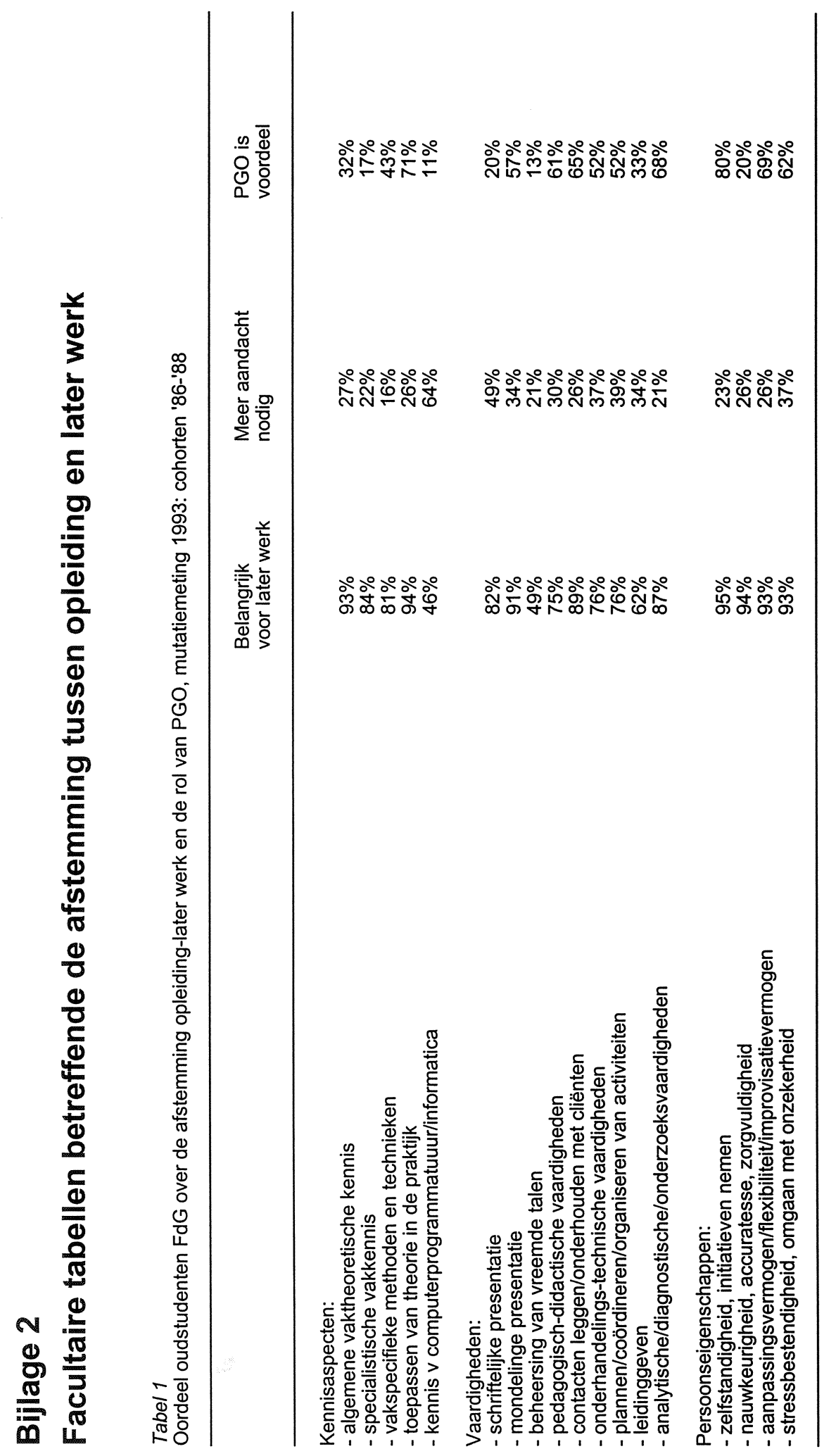




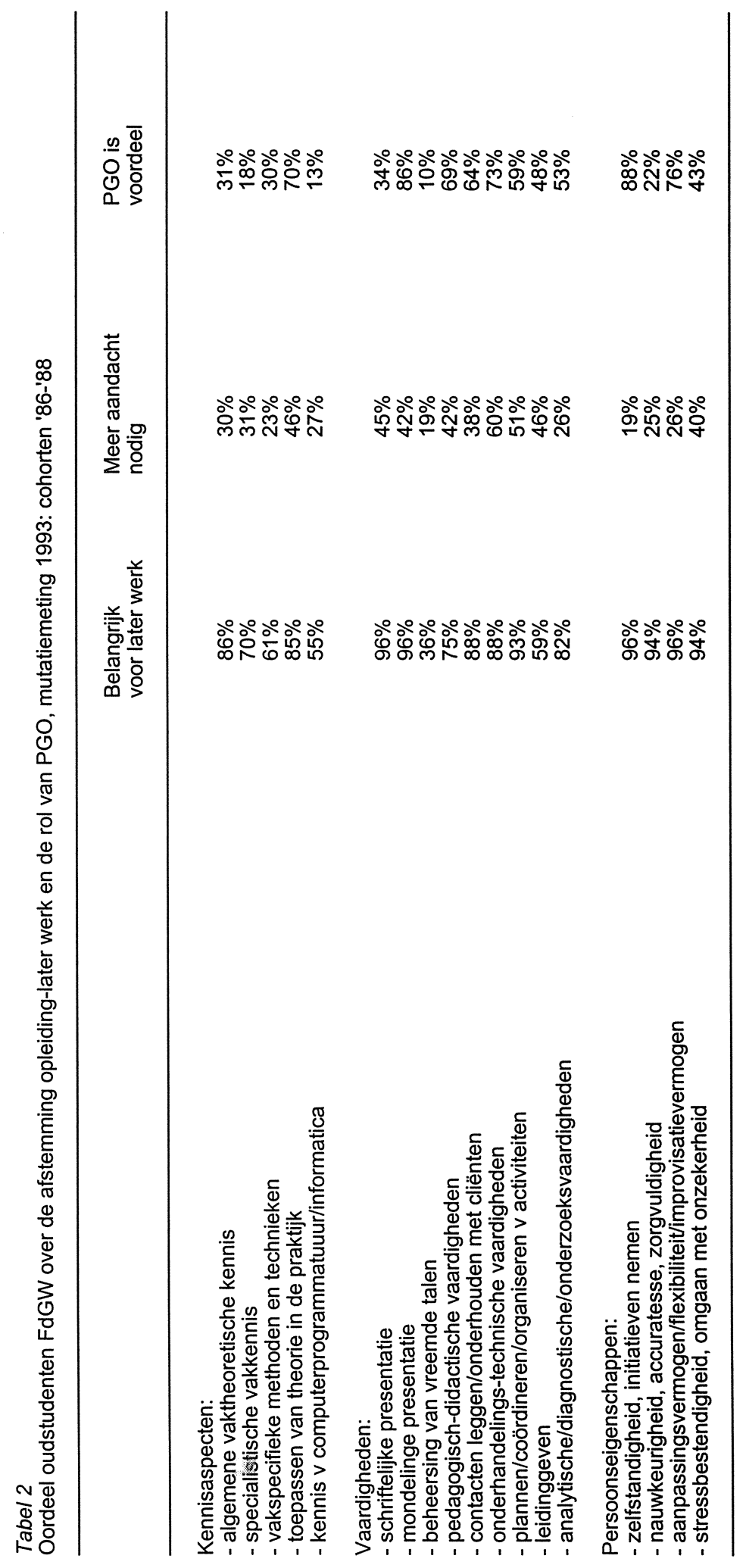




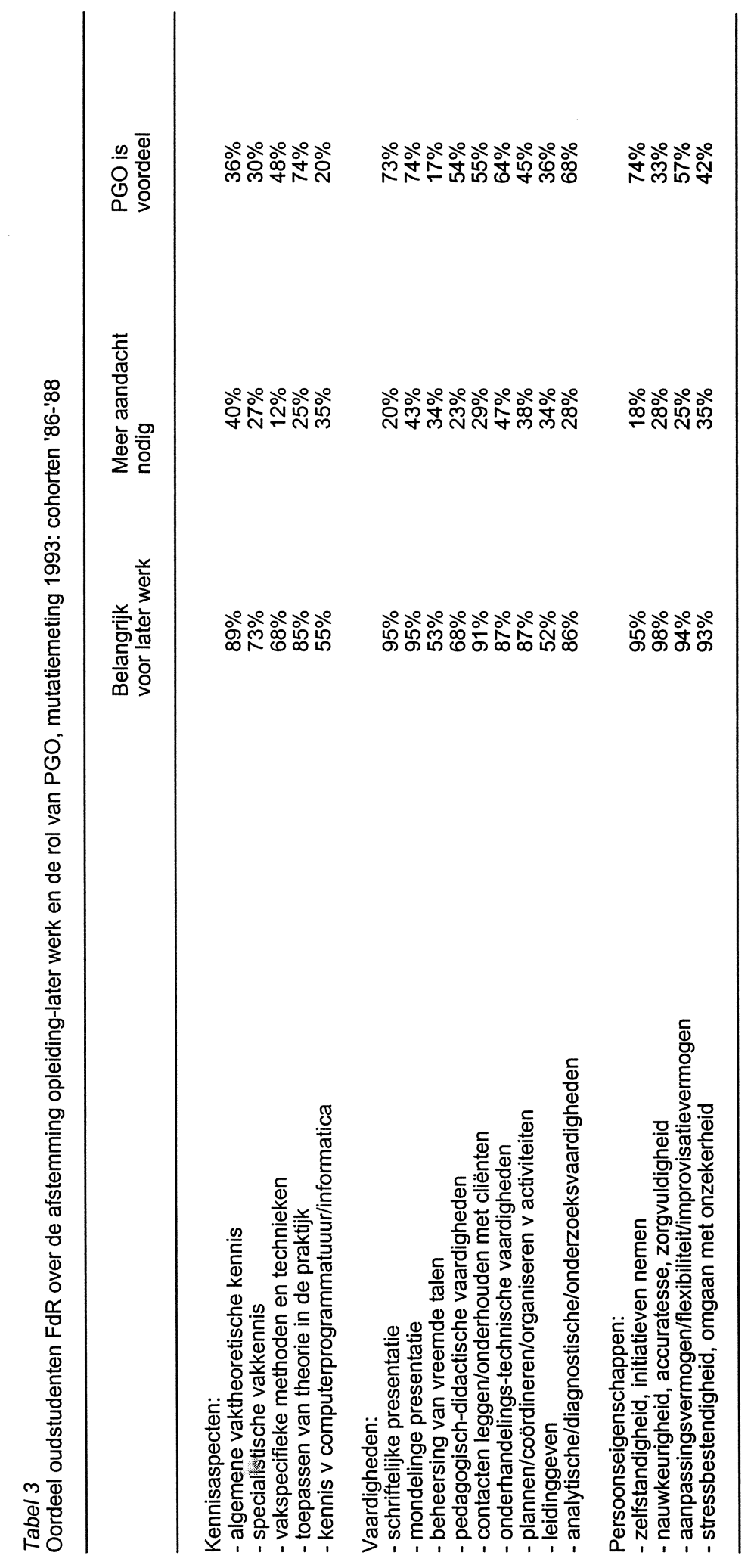




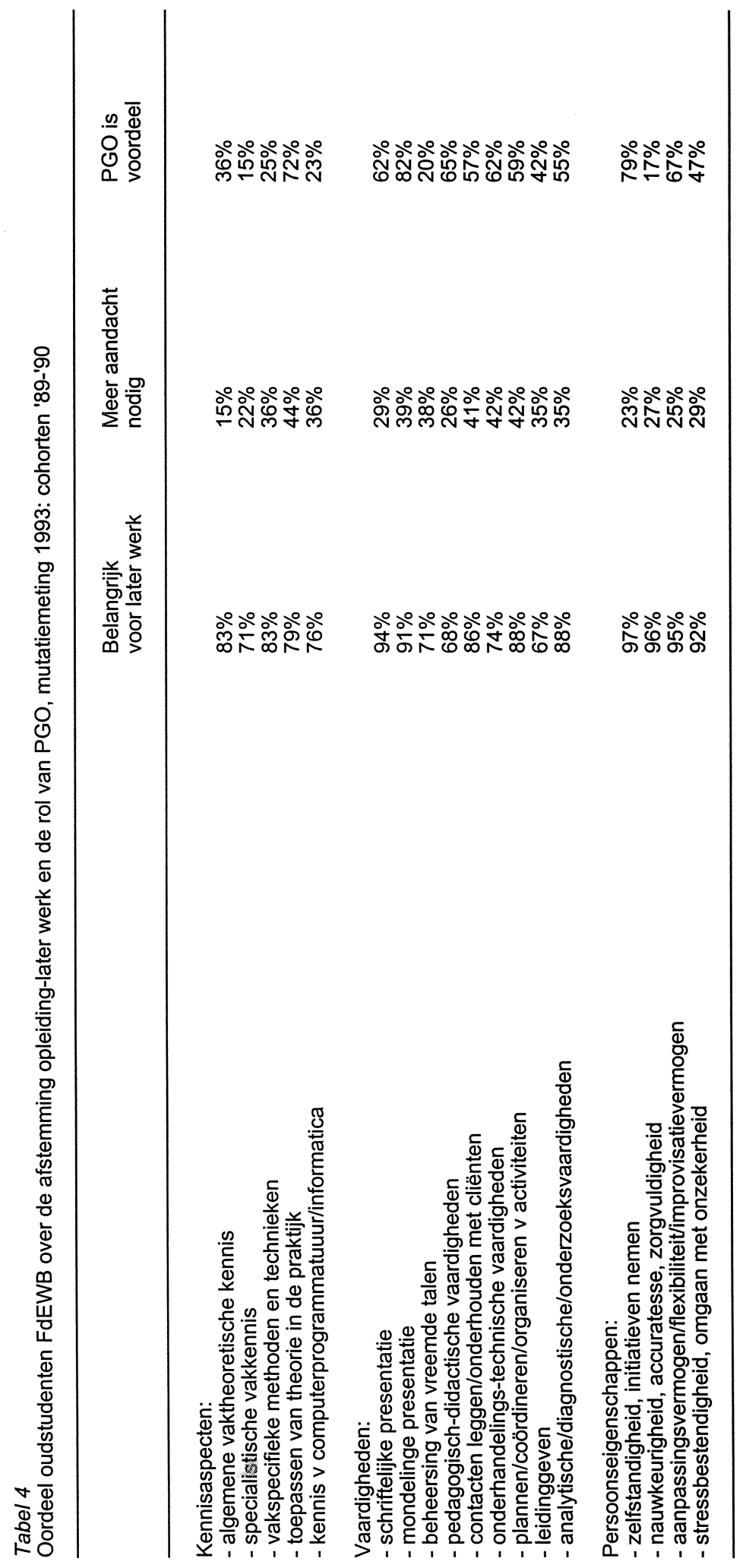




\section{Bijlage 3 \\ Definitie van variabelen in de schattingen}

Te verklaren variabelen

Werk op WO-niveau*

Leidinggevend werk*

Bruto maandloon*

Belang persoonseigenschappen*

Belang vakkennis*

Belang managementvaardigheden*

Belang schriftelijke vaardigheden*

Gewenste aandacht voor managementvaardigheden

Gewenste aandacht voor persoonseigenschappen

dummy $=1$ indien voor de baan (door de werkgever) een opleiding op academisch nisveau werd vereist.

dummy $=1$ indien leiding aan andere medewerkers wordt gegeven.

in de $t+1$ meting het bruto maandloon in de hoofdfunctie bij een volledige werkweek en logaritmisch getransformeerd; in de $t+5$ meting het bruto maandloon in de hoofdfunctie (inclusief toeslagen voor onregelmatig werk en ploegendienst, doch exclusief inkomsten uit overwerk en bijzondere uitkeringen), omgerekend naar een veertigurige werkweek en logaritmisch getransformeerd.

factorscores op de kwalificatie-items:

- aanpassingsvermogen, flexibiliteit, improvisatievermogen;

- stressbestendigheid, omgaan met onzekerheid;

- zelfstandigheid, initiatieven nemen;

- nauwkeurigheid, accuratesse, zorgvuldigheid;

- mondeling presenteren.

factorscores op de kwalificatie-items:

- specialistische vakkennis;

- vakspecifieke methoden en technieken;

- algemene vaktheoretische kennis;

- toepassen van theorie in de praktijk.

factorscores op de kwalificatie-items:

- leidinggeven;

- plannen, coördineren en organiseren van activiteiten;

- onderhandelings-technische vaardigheden.

factorscore op het kwalificatie-item: 'schriftelijk presenteren'.

factorscores op de kwalificatie-items:

- leidinggeven;

- plannen, coördineren en organiseren van activiteiten;

- onderhandelings-technische vaardigheden.

factorscores op de kwalificatie-items:

- aanpassingsvermogen, flexibiliteit, improvisatievermogen;

- stressbestendigheid, omgaan met onzeker- 
heid;

- zelfstandigheid, initiatieven nemen.

Gewenste aandacht voor M\&T

Gewenste aandacht voor schriftelijke vaardigheden

Gewenste aandacht voor computervaardigheden

Gewenste aandacht voor vreemde talen

* Ook als verklarende variabele.

Verklarende variabelen

Geslacht: man

Leeftijd

Gezinssituatie:

- alleenstaand

- gehuwd/samenwonend zonder kind

- gehuwd/samenwonend met kind

HO-vooropleiding

Relevante werkervaring

Bestuurlijke ervaring

Gevolgde opleiding;

- Geneeskunde

- Gez. wet.

- Ned. recht

- Economie

Studieduur

Duur intredewerkloosheid factorscore op het kwalificatie-item: 'vakspecifieke methoden en technieken'.

factorscore op het kwalificatie-item: 'schriftelijk presenteren'.

factorscore op het kwalificatie-item: 'kennis van computerprogrammatuuur en informatica'.

factorscore op het kwalificatie-item: 'beheersing van vreemde talen'.

dummy $=1$ indien respondent man is.

leeftijd in jaren in het jaar van afstuderen.

dummy $=0$ indien alleenstaand (referentiecategorie);

dummy = 1 indien gehuwd/samenwonend zonder kind(eren);

dummy = 1 indien gehuwd/samenwonend met kind(eren).

dummy = 1 indien respondent voor aanvang van UM-studie een HBO- of WO-oplei ding heeft voltooid.

dummy = 1 indien respondent voor het vakgebied relevante betaalde werkervaring heeft opgedaan vóór afstuderen.

dummy = 1 indien respondent bestuurlijke ervaring heeft opgedaan vóór afstuderen.

dummy $=0$ indien afgestudeerd in geneeskunde (referentiecategorie);

dummy $=1$ indien afgestudeerd in gezondheidswetenschappen;

dummy = 1 indien afgestudeerd in Nederlands recht;

dummy = 1 indien afgestudeerd in economie.

aantal jaren tussen kalenderjaar aanvang en kalenderjaar einde desbetreffende opleiding.

aantal maanden werkloos tussen het afstuderen en de eerste betaalde baan na het afstuderen. 
Post-doctorale onderwijskwalificaties:

- Geen vervolgopleiding

- Bezig vervolgopleiding

- Vervolgopleiding voltooid

Vroegere werkervaring

Opleidingsrichting:

- Geneeskunde

- BB

- GVO

$-V W$

- Ned. recht

Werk in eigen richting

Combineren werken-leren

Vervolgonderwijs voltooid

Duur loopbaan

Grotere organisatie

Profit sector dummy $=0$ indien $2 \mathrm{e}$ fase-opleiding of postdoctorale beroepsopleiding nooit gevolgd of voortijdig verlaten (referentiecategorie);

dummy $=1$ indien $2 e$ fase-opleiding of postdoctorale beroepsopleiding thans wordt gevolgd;

dummy $=1$ indien $2 e$ fase-opleiding of postdoctorale beroepsopleiding is voltooid.

dummy = 1 indien respondent betaalde werkervaring heeft opgedaan vóór afstuderen.

dummy $=0$ indien afgestudeerd in geneeskunde (referentiecategorie);

dummy = 1 indien afgestudeerd in beleid en beheer;

dummy = 1 indien afgestudeerd in gezondheidsvoorlichting;

dummy = 1 indien afgestudeerd in verplegingswetenschap;

dummy $=1$ indien afgestudeerd in Nederlands recht.

dummy = 1 indien voor de baan (door de werkgever) de zelf gevolgde opleidingsrichting of een daaraan verwante richting werd vereist.

dummy = 1 indien de baan wordt gecombineerd met het volgen van een $2 e$ fase-opleiding of post-doctorale beroepsopleiding.

dummy $=1$ indien $2 \mathrm{e}$ fase-opleiding of postdoctorale beroepsopleiding voltooid.

aantal maanden dat men reeds is afgestudeerd.

$1=$ werkorganisatie met $1-9$ personeelsleden;

2 = werkorganisatie met $10-19$ personeelsleden;

3 = werkorganisatie met 20-49 personeelsleden;

4 = werkorganisatie met $50-99$ personeelsle-

den;

$5=$ werkorganisatie met 100-199 personeelsleden;

6 = werkorganisatie met 200-499 personeelsleden;

7 = werkorganisatie met 500 personeelsleden of meer.

dummy = 1 indien respondent werkt in een profit-organisatie. 